\title{
Firm-Specific Characteristics And The Disclosure Level: Evidence From The Tehran Stock Exchange
}

Ali Saeedi, University of Minnesota, USA

Reza Daghani, Allameh Tabataba'i University, Iran

Najmeh Hajian, Khatam University, Iran

\begin{abstract}
This paper studies the relationship between the disclosure level and firm-specific characteristics of firms listed on the Tehran Stock Exchange (TSE). Our study contributes to the firm financial disclosure literature by documenting the empirical evidence on the relationship between CEO tenure and firm disclosure. We use firms' disclosure scores released by the Iranian Securities and Exchange Organization (SEO) that measure the disclosure level of listed companies. The research data consists of 2,719 firm-year observations from 404 Iranian listed firms on the TSE for 2003-2014. Using regression analyses, we find that longer CEO tenure improves the level of disclosure. Also, we document that firm profitability, liquidity, and asset-in-place have a positive effect on the disclosure level. Moreover, we report that leverage, age, and market share have an inverse effect on the disclosure level.
\end{abstract}

Keywords: Firm Disclosure; Firm-Specific Characteristics; CEO Tenure; Tehran Stock Exchange

\section{INTRODUCTION}

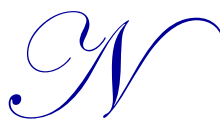

umerous researchers have examined the relationship between the degree of financial disclosure and firm characteristics in developed countries (Barrett, 1977; Lang \& Lundholm, 1993; Wallace, Naser, \& Mora, 1994; Camfferman \& Cooke, 2002; Ali, Klasa, \& Yeung, 2014). However, little studies have investigated the relationship between the disclosure level and company characteristics in the Middle Eastern countries, specifically Iran. Several reasons make this study worthy of attention. Firstly, we contribute to the disclosure literature on the basis of this idea that the theories tested in the developed countries may well not explain the disclosure environment of the Iranian capital market. In Iran, the level of state ownership, capital market structure, institutional and political conditions are significantly different from developed countries (Mohammadrezaei, Mohd-Saleh, \& Banimahd, 2012). Secondly, the Iranian economy is ranked as the eighteenth largest economy in the world using Purchasing Power Parity (PPP) and is the second economy in the region of the Middle East and North Africa (MENA) (The World Bank, 2017). Thirdly, Iran is a member of the Next Eleven, also known as N-11 (O'Neill, Wilson, Purushothaman, \& Stupnytska, 2005). Iran's economy could hit a growth spurt (Cole, 2016) and attract more foreign investors. Fourthly, some events, including privatization and stock market reforms, the ratification of the Iranian Securities Market Act, and the bylaw governing Foreign Investment in the Exchanges and OTC Markets have fundamentally changed the Iranian capital market environment. Lastly, the Iranian Accounting Standards convergence with the International Financial Reporting Standards (IFRS) and formation of the Iranian Association of Certified Public Accountants (IACPA) in 2001 affected the accounting and auditing profession. These factors and developments significantly affect Iranian companies' disclosure level.

We use firms' disclosure scores released by the Iranian Securities and Exchange Organization (SEO) that measure the disclosure level of companies. The research data consists of 2,719 firm-year observations from 404 companies listed on the TSE for 2003-2014. We employ regression models to analyze the relationship between the disclosure level and the firm-specific characteristics. 
Our study contributes to the literature on financial disclosure of companies and its determinants at the international level by presenting some evidence from a developing country as follows. First, we find that longer CEO tenure enhances the level of disclosure. Second, we document that the listed companies audited by the Iranian Audit Organization have lower disclosure scores due to the delay in filing their financial reports to the TSE. Third, confirming the findings of Cooke (1989a) and Camfferman \& Cooke (2002), we show that the companies operating in Chemical, Pharmaceutical, and Cement \& Plaster industries have a higher disclosure score and disclose more information. Also, we document that firm profitability, liquidity, and asset-in-place have a positive effect on the disclosure level. Moreover, we report that leverage, age, and market share have a negative effect on the level of disclosure.

The rest of this paper is organized as follows: Section 2 clarifies the information disclosure and financial reporting environment in Iran. Section 3 outlines the related literature and explains the determinants of corporate disclosure. Section 4 explains the research variables and hypotheses development. Section 5 covers the research methodology, including data collection and the research regression model. Sections 6 and 7 report the analyses of empirical results and the sensitivity analysis, respectively. The last section covers our conclusions and future research suggestions.

\section{FINANCIAL ACCOUNTING AND REPORTING IN IRAN}

During the recent three decades, various measures induced improvement in the accounting and auditing practices in Iran. In the first place, corporate disclosure has been enforced by the Iranian Commercial Code of 1932. The other event was the establishment of the Tehran Stock Exchange (TSE) in early 1967. The TSE has approved some regulations on accounting and auditing practices, including mandating auditing of listed firms by external certified public accountants. During the 1970s, some movements like passing ownership of state-owned companies to their employees and the public induced expansion in the stock market activities. Then there was a stagnation from 1979 (year of the Revolution in Iran) to 1989. After the stagnation period, the privatization activities continued based on the country's Development Plan, and as a result, the need for improvement in the disclosure of financial information has been elevated (Mashayekhi \& Mashayekh, 2008).

Both the Commercial Code and the Security Market regulations govern corporate financial reporting of listed firms in TSE. The Iranian Commercial Code sets a generic framework for activities and reporting of all the registered firms in Iran and specifies some critical provisions with respect to the Iranian Constitution. Other laws and acts stipulate different aspects of activities and reporting for firms. In the capital market, all participants are required to operate in compliance with the Iranian Security Market Act, approved in November 2005. Under the Act, the Securities and Exchange Organization (SEO) ${ }^{1}$ is responsible for controlling of financial activities and disclosure policies (Sadeghi Moghadam \& Norouzi, 2012). In August 2007, SEO published some regulations about specific policies on firms' disclosure. These regulations clarify all the required information items to be disclosed by companies listed on TSE and address requirements related to them. ${ }^{2}$ It is worthwhile to mention that in Iran, the Iranian Audit Organization (IAO) is in charge of the development and implementation of accounting and auditing standards. The organization established in 1987 as a statutory body to govern the accounting profession. A committee of audit organization was responsible for setting national accounting and financial reporting standards from 1992. This committee has approved more than 35 national accounting standards. It is worth mentioning that those standards converge, to a large extent, with the International Financial Reporting Standards (IFRS). The establishment of the Iranian Association of Certified Public Accountants (IACPA) in 2001 was another development that affected the accounting and auditing practices. IACPA regulates and promotes accounting and auditing profession in the country and oversights the professional practices of its members.

\footnotetext{
1 "The Securities and Exchange Organization of Iran (SEO) was established in 2006 after the Tehran Stock Exchange demutualization and, as Article 5 of the Securities Act ratified by the Islamic Consultative Assembly on November 22 ${ }^{\text {nd }}, 2005$ " (Tehran Stock Exchange, 2009).

${ }^{2}$ For example, listed firms on TSE are required to disclose their significant events, quarterly reports and the details of the decisions taken in their general meetings.
} 
The other improvement in the Iranian financial disclosure setting was the introduction of a Corporate Governance

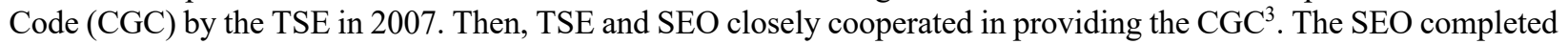
and formally adopted the CGC in 2010 (Braendle, Omidvar, \& Tehraninasr, 2013). Finally, the last version of the CGC presented by SEO in 2014, which includes five chapters on accountability. The disclosure is one of these main chapters, which includes articles and notes about the level, quality, and locality of corporate information. Altogether, the Corporate Governance Code and establishment of TSE, SEO, IAO, and IACPA might affect the financial disclosure quality.

\section{LITERATURE REVIEW}

Since the 1960s, interest in the financial disclosure studies has increased. Corporate disclosure has attracted the attention of many researchers, both in developed countries, such as UK (Firth, 1979; Frost, 1997); the USA (Buzby, 1975; Lang \& Lundholm, 1993; Belkaoui, 2001); Canada (Belkaoui \& Kahl, 1978); Hong Kong (Wallace \& Naser, 1995); Sweden (Cooke, 1989a, b); Japan (Cooke, 1992); France (Depoers, 2000); New Zealand (Hossain, Ahmad, \& Godfrey, 2005); Spain (Urquiza, Navarro \& Trombetta, 2010); and in developing countries, such as China (Wang, O \& Claiborne, 2008); Qatar (Hossain \& Hammami, 2009); Malaysia (Akhtaruddin, Hossain, Hossain, \& Yao, 2009; Ghazali \& Weetman, 2006); Jordan (Naser, Al-Khatib, \& Karbhari, 2002); and Kenya (Barako, 2007). Also, some studies (e.g., Camfferman \& Cooke, 2002; Chau \& Gray, 2002; Zarzeski, 1996) have investigated the financial disclosure in two or more countries.

Empirical results provide mixed evidence about the relationship between a firm's characteristics and its disclosure level. Different socio-economic and political environments between countries (Ahmed \& Courtis, 1999), various statistical methods and indices construction and extent are some of the potential reasons that could consider for these dissimilar conclusions (Wallace, et al. 1994). Due to these unclear results, some researchers like Ahmed \& Courtis (1999) tried to integrate previous research on the relationship between firm characteristics and disclosure to determine the fundamental factors that mitigate the evident variation in the results. Marston \& Shrives (1991) reviewed previous studies about disclosure before 1986 and indicated that the corporation's size, listing status, leverage, profitability, and auditor size were the most common variables investigated concerning the degree of disclosure. Albeit, there was a significant relationship between the company size and listing status and the level of disclosure, they determined that the findings were incomplete with respect to leverage, profitability, and the auditor size. Later, Marston \& Shrives (1995) in a review of 32 studies found inconsistent results regarding the relationship between profitability, leverage, audit firm size, and the level of disclosure (Ahmed \& Courtis, 1999). Berglöf \& Pajuste (2005), using a sample of 370 companies listed in Eastern and Central Europe, found that larger companies, and companies with lower leverage, higher market-to-book ratios, and concentrated ownership disclose more information. Ahmed \& Courtis (1999) by performing a meta-analysis of 29 research papers in the disclosure area indicated that there is a significant and positive relationship between the level of disclosure and firm size, listing status, and leverage.

Urquiza et al. (2010) studied the relationship between firm characteristics and disclosure in Spanish companies. The results of their study showed that disclosure of the information is affected by the firm's size and financial leverage. Other studies declare that disclosure differs in response to the size of the board, the ratio of independent non-executive directors (INDs) and family control (Akhtaruddin et al. 2009); the percentage of government ownership, foreign ownership, company performance, and auditor reputation (Wang et al. 2008); corporate governance attributes, company size, and type of industry (Barako, 2007).

There are a few documents about the relationship between disclosure and firm characteristics in the TSE. Kamalian, Niknafs, Afsharizadeh, \& Gholamalipoor (2010), using the C5.0 decision tree algorithm, documented a significant and positive relationship between the disclosure and high profitability, low leverage, and type of auditor. Khaleghi Moghadam \& Khalegh (2008) investigated the relationship between corporate disclosure and ownership structure, financial leverage, the board of directors' composition, and profitability. They indicated that disclosure is influenced

\footnotetext{
${ }^{3}$ The purpose of the Corporate Governance Code (CGC) is to assure that the shareholders' rights are protected. Enhancing corporate disclosure is one of the most important aspects of a satisfactory corporate governance. It is worth mentioning that the code has been introduced to improve accuracy of information disclosed by companies for establishing a reliable relation between company stockholders, board of directors, and management.
} 
by size but not other factors. Their results supported by Allahdad (2010). He showed a positive relationship between the disclosure level, measured by S\&P transparency and disclosure models, and company size. Hajian, Anvary Rostamy, Rahmani, \& Azar (2015) examined five categories of a firm's characteristics that were found as affecting factors on disclosure level by 32 prominent studies. Their results indicated that a favorable position in liquidity and profitability encourages managers to disclose more information. However, they found no relationship between disclosure and other variables, like the size of the company, age, or financial leverage.

\section{RESEARCH VARIABLES AND HYPOTHESES DEVELOPMENT}

We follow Lang \& Lundholm (1993), Wallace et al. (1994), Camfferman \& Cooke (2002), and Alsaeed (2006) to classify the firm-specific characteristics into three categories as structure-related variables (company size, assets-inplace, leverage, equity issue, and age), performance-related variables (profitability and liquidity), and market-related variables (market share, type of industry, and auditor type). We also investigate the effect of CEO tenure.

\subsection{CEO Tenure (CEOTEN)}

One of the firm-specific characteristics that affects corporate disclosure is an informational asymmetry between corporate managers and investors (Verrecchia, 1990). Lang \& Lundholm (1993) and Welker (1995) documented a relationship between corporate disclosure level and information asymmetry. There are two approaches to lessen the informational asymmetry between managers of the company and investors. One of those is to disclose more information for tracking management strategies. Another approach is to hire a CEO with the incentives that are in alignment with the interests of shareholders. In the case of unsatisfactory performance, a CEO is replaced because the firm's owners conclude that he/she is ineffective in implementing the appropriate strategies and policies that create value for shareholders (Dikolli, Keusch, Mayew, \& Steffen, 2014). Thus, there are two opposite theoretical viewpoints about the relationship between disclosure policy and CEO tenure. In one view, an expanded disclosure policy improves a firm's information environment and allows for greater monitoring that keeps managers from undertaking actions against shareholders' interest. Thus a negative relation between disclosure and CEO tenure is predicted (Bamber, Jiang, \& Wang, 2010). As the length of the CEO-firm relationship increases, a decrease in the information asymmetry is expected. Thus a CEO does not have much incentive to disclose information to investors (Peterson, 2010). In another viewpoint, an expanded disclosure policy limits managerial ability to manipulate financial measures and improves the board of directors' ability to assess the CEO; therefore a positive relationship between corporate disclosure policy and CEO tenure is expected (Clarkson, Kao, \& Richardson, 1999; Peterson, 2010). Thus, based on the above arguments, we hypothesize:

H1: Firms with longer-tenured CEOs are more likely to have a higher disclosure level than firms with shorter-tenured CEOs.

\subsection{Firm Size (SIZE)}

As a surrogate for the relative cost of information disclosure and also as a proxy for the significance of the financial statements in presenting timely information for external users, we include firm size in our model. Large firms have more external providers of funds and, therefore, experience more external pressure than small firms to report timely (Ahmed \& Courtis, 1999; Botosan, 2000; Malone, Fries, \& Jones, 1993). Large firms are more likely able to bear the disclosure cost better than small ones (Deloof \& Weets, 2003). Owusu-Ansah (1998) and Stigler (1961) documented that, due to the economies of scale in providing information, the disclosure level might be affected by the firm size. Many empirical studies find a positive relationship between company size and the financial disclosure in listed firms (Bamber et al. 2010; Owusu-ansah, 2000). Thus, we hypothesize:

$\mathbf{H}_{2}$ : Larger firms are more likely to have a higher disclosure level than small firms.

To stay away from inclination emerging from exposure opportunities that happen more in large firms than in small ones, we divide our research sample into large and small based on the median of variable SIZE (13.24). It may offer some useful insight into how large and small firms differ operationally. 


\subsection{Assets-in-Place (ASSETPLC)}

The ratio of assets-in-place (ASSETPLC) is calculated by dividing the net book value of tangible fixed assets by total assets. Butler, Kraft, \& Weiss (2007) indicated that companies with high information asymmetry and high agency costs might report more information to reduce asymmetry. On the contrary, they suggested that firms with high proprietary costs might report less information. Myers (1977) categorizes company assets into two groups of assets that are already in possession of the company and those yet to be earned. He then suggests that the transfer of wealth between shareholders and debt holders could be more difficult with assets that are already owned. This indicates an inverse relationship between the level of financial disclosure and corporate assets-in-place. Previous studies (Chow \& Wong-Boren, 1987; Hossain, Perera, \& Rahman, 1995; Raffournier, 1995) documented no relationship between assets-in-place and the level of voluntary disclosure in developed and developing countries. Contrarily, Hossain \& Hammami (2009) showed a significant relationship between the ratio of assets-in-place and voluntary disclosure. There is inconclusive evidence on the relationship between these two variables. Therefore, based on the above discussions, we hypothesis:

H3: Firms with a large ratio of assets-in-place are more likely to have a lower level of disclosure than firms with a small ratio of assets-in-place.

\subsection{Leverage $(L E V)$}

Prior research suggests that highly leveraged companies tend to disclose more information to satisfy the needs of their creditors, which is followed by higher agency costs in their capital structure. It indicates that there is a positive relationship between a firm's leverage and its disclosure level in the case of higher agency costs (Deloof \& Weets, 2003). In developing countries where financial institutions are considered as an essential source of funds for a company, it is expected that firms with sizable debts on their financial statements to disclose more information. Moreover, such firms tend to prepare detailed information to increase the likelihood of obtaining the needed funds. Contrarily, Baiman \& Verrecchia (1996), Frost (1997), Healy, Hutton \& Palepu (1999), Healy \& Palepu (2001) argued that financing arrangements reduce managers' incentives to provide public disclosures. The empirical research results, to date, are contradictory. We use the ratio of total debts to total assets as a surrogate for leverage. Consequently, we hypothesize:

$\mathbf{H}_{4}$ : Highly leverage firms are more likely to have a higher disclosure level than less leveraged firms.

\subsection{Equity Issues (ISSUE)}

Choi (1973), Diamond \& Verrecchia (1991), and Clarkson et al. (1999) suggest that external financing needs motivate managers to provide more information. Firms managers try to decrease the cost of raising additional funds by reducing information asymmetry. The disclosure of additional information decreases informational asymmetry, and whereby furthers accessing to the capital market at low cost (Lang \& Lundholm, 1993, 1996; Tasker, 1998; Healy et al. 1999). Correspondingly, we hypothesize that there is a positive relationship between disclosure level and our measure of external funds needs:

Hs: Firms that have frequent access to capital markets are more likely to have higher disclosure levels than firms with infrequent access.

Consistent with previous research (Clarkson et al. 1999; De Jong, Verbeek, \& Verwijmeren, 2011; Korajczyk \& Levy, 2003; Leary \& Roberts, 2005), we use a dichotomous indicator variable when the percentage of new share issues is at least 5 percent of the book value of total assets at the beginning of the fiscal year.

\subsection{Firm Age $(A G E)$}

Alsaeed (2006) and Hossain \& Hammami (2009) studied the company age effect on the disclosure level, based on the rationale that firms' financial reporting practices improve, as they get older. Owusu-Ansah (1998) argued that a firm's level of disclosure might be affected by age. He hypothesized that older companies probably disclose more information 
than younger companies. The argument is based on three considerations. First, younger firms might experience competitive disadvantages due to the disclosure of specific information like capital expenditure, research expenditure, and product development. Second, collecting, processing, and distributing information are presumably costlier for younger firms. Third, younger firms may have no dependable "track record" to be used for public disclosure. Thus, it is expected that an older, well-established company will have a higher disclosure level than a younger firm. We measure corporate age from the date of listing the firm on the TSE. Consequently, we develop the following hypothesis:

H6: Older firms are more likely to have a higher disclosure level than younger firms.

\subsection{Profitability $(P R O F)$}

Earnings margin is a measure of profitability that we operationalize as a ratio of net earnings after interest and tax to sales. Singhvi \& Desai (1971) contended that managers of highly profitable firms tend to provide more information to convince their shareholders that the company has a steady condition and to further their managerial compensations. Lang \& Lundholm (1993) argued that corporate performance affects the disclosure level; however, there is inconclusive evidence about the direction of the relationship. Profitable corporate managers are expected to provide additional information to reveal their exceptional achievements and also preclude the undervaluation of their stocks (Ferreira, Branco, \& Moreira, 2012; Hossain et al. 2005). However prior research has documented inconclusive evidence about the relationship as mentioned above, some studies indicated that almost profitable companies tend to disclose additional information (Hossain \& Hammami, 2009; Owusu-Ansah, 1998; Palmer, 2008; Verrecchia, 1990; Wallace \& Naser, 1995). On the contrary, Lang \& Lundholm (1993) and Wallace et al. (1994) found no conclusive results concerning the relationship between company profitability and disclosure. We hypothesize:

H7: Firms with higher earnings margins are more likely to disclose more information than firms with lower earnings margins.

\subsection{Liquidity (LIQUID)}

The current ratio is a measure of liquidity because the ratio is employed by short-term creditors to assess a company's capability to satisfy its current liabilities. Prior studies (Belkaoui \& Kahl, 1978; Cooke, 1989a, 1989b) indicated that there is a positive relationship between liquidity and the level of disclosure. It is formed on the assumption that a healthier financial position of a company can induce the management to disclose information to signal the better position of a company to the market. On the other hand, it may be contended that a weaker position motivates the management to disclose in order to mitigate concerns and communicate with shareholders that managers are dealing with the situation (Camfferman \& Cooke, 2002). Wallace et al. (1994) indicated that a company with poor liquidity conditions is predicted to provide additional information to rationalize its liquidity position. The literature shows that there are inconclusive results about the relationship between a company's liquidity and disclosure level. Belkaoui \& Kahl (1978) and Alsaeed (2006) indicated that there is a positive but insignificant relationship between firm liquidity and disclosure. Contrarily, Wallace et al. (1994), Wallace \& Naser (1995), and Naser et al. (2002) documented a negative relationship between company liquidity and disclosure. We hypothesize that:

Hs: Firms having a higher liquidity ratio are more likely to disclose more information than firms having a lower liquidity ratio.

\subsection{Market Share (PINREV)}

Based on the argument that market-leading companies take almost all the growth opportunities as they become larger, we include the firm's market share in our model. When a company has a sizable share of the market, it will be benefited "from economies of scale, lower cost of capital, and monopoly power in future economic rents" (Hossain et al. 2005, p. 884). In this study, we use the company's relative market share as a surrogate for the relative competitive advantage of the firm (Hansen \& Wernerfelt, 1989). The question of how disclosure by a company changes with its competitive situation has received much attention in the literature (Dedman \& Lennox, 2009; Beyer, Cohen, Lys, \& Walther, 2010; Ali et al. 2014). The concentration rate of a company's sales is a crucial factor in assessing the inherent risks in a 
company's revenue. When a company has monopoly power in an industry, it does not have much stimulus to disclose information. In a more concentrated industry, firms have more interdependent investment strategies with rivals, and incumbents in competitive industries prefer less informative disclosure policies (Ali et al. 2014). Thus, more disclosing is expected with increasing the degree of competition in the industry to attract potential investors. Since information regarding a company helps investors to assess an industry's prospect, we suggest that the capital market appeals for disclosure of information. Following the above arguments, we hypothesize:

H9: Firms with large market share are more likely to disclose more information than firms with small market share.

\subsection{Auditor Type (AUDIT)}

Auditor size is a traditional surrogate for audit quality. The audit companies are categorized into large and small groups on the basis of the assumption that large audit companies take care of their reputation and accordingly prefer to be associated with companies that disclose more information (Alsaeed, 2006; Firth, 1979; Wallace \& Naser, 1995). Our literature review shows that most findings concerning auditor size are from the contexts where auditors are obligated to provide high-quality audits due to high litigation risk in their environments. But, in the case of low litigation risk and lack of substitute disciplinary procedures that encourage providing high-quality audits, auditors are not motivated enough to avoid involving poor-quality audits (Azizkhani, 2011). To the best of our knowledge, there is no case of a lawsuit against auditors in Iran as of the date of this study. In the absence of litigation risk, the auditor would have little incentive to commit the required attempt or issue accurate reports (Dye, 1993). As another different aspect of the Iranian context, Big 4 audit firms are absent in providing audit services in this country. Because of the limited litigation risk and lack of reputation risk for Big 4 audit firms, we face a unique setting to study the relationship between auditor type and company disclosure level. Iranian Audit Organization (IAO) is known as one of the largest shares of audit firms in the audit market of the country. To stimulate economic recovery, the Iranian government attempted to transfer ownership of state-owned companies to the private sector in its privatization practices (Azizkhani, 2011; Wijewardena \& Roudaki, 1997). The Iranian government monitors this privatization process by employing IAO audit services (Azizkhani, 2011). We use IAO as a proxy for government monitoring of governmentcontrolled firms. In an audit market where the litigation and reputation risks have no critical role in driving higher quality audits, it is unlikely to experience a quality differentiation between audits provided by public and private audit firms. Consequently, we hypothesize:

$\mathbf{H}_{10}$ : Firms audited by the Iranian Audit Organization (IAO) are likely to have the same disclosure level as firms audited by private-sector auditors.

\subsection{Industry Type (INDUSTRY)}

Owusu-Ansah (1998) hypothesized that companies operating in different industries are expected to demonstrate different disclosure behaviors. Moreover, Wallace et al. (1994) argued that firms doing business in a particular industrial section might apply disclosure methods in addition to those mandated for all industry sectors. Regarding industry-type variable, Cooke (1992) asserted that levels of disclosure are likely different in companies operating in distinct economic sectors. Because of the fear that a firm's competitors may benefit from the disclosed information, its management decides not to disclose information. This concern presumably varies among industries and may induce industry differences in disclosure (Stanga, 1976). Some prior studies indicated that there is a relationship between industry-type and disclosure level (Belkaoui \& Kahl, 1978; Camfferman \& Cooke, 2002; Cooke, 1989a; Ferguson \& Stokes, 2002; Meek, Roberts, \& Gray, 1995; Stanga, 1976). On the contrary, Wallace et al. (1994) and Owusu-Ansah (1998) documented that there is an insignificant relationship between industry-type and firm disclosure level. Cooke (1989b) argued that trading firms are expected to have a lower level of disclosure than firms operating in other industries do. Based on the preceding discussions, we hypothesize:

$\mathbf{H}_{11}$ : Firms operating in distinct economic sectors are likely to have different levels of disclosure. 


\subsection{Data Collection}

\section{RESEARCH METHOD}

We collected the research data for Iranian listed firms on the TSE from 2003 to 2014. Our research period begins in 2003 when firms' disclosure scores are available from SEO. The research data is collected from the Securities and Exchange Organization (rdis.ir), the Tehran Securities Exchange Technology Management Co., and the Rahavard Novin database. These data sources are established databases in the Iranian context that have been using for years. They form their databases using the Comprehensive Database of All Listed Companies (CODAL), which belongs to SEO. After excluding financial firms (e.g., Banks, Insurance, and Investment firms), due to different characteristics of their financial reports, we have 2,719 firm-year observations for 404 firms.

\subsection{Disclosure (DISCLOS) as Dependent Variable}

Previous studies indicate that, since the disclosure is a conceptual substance, quantifying it in a precise manner is unclear (Botosan, 1997; Healy \& Palepu, 2001). Thus it is indirectly observed through the values of the recognized variables (Hassan \& Marston, 2010). Following previous studies, we use a proxy measure to track a firm's capacity for information disclosure. The measure of disclosure refers to the entire annual report and other information released by management to evaluate the disclosure level. The disclosure score, as a convenient tool, could be employed in ranking firms' disclosure levels. Therefore, we apply firms' disclosure scores released by the Iranian Securities and Exchange Organization (SEO) as a measure of the corporate level of disclosure. The construct of financial disclosure score consists of two criteria, timeliness and reliability of submitted information to the SEO. The SEO and TSE rules require firms to disclose in a timely manner all material information that is expected to affect the price of a firm's stock considerably. The initial Securities Market Act of 2001 provides the principles for the firm's public disclosure. If a firm meets the SEO and TSE requirements, it will be given the appropriate points in the disclosure measure. The points will show the results of the evaluation by the TSE and SEO, regarding the level of firm's informativeness and timeliness. The firm's score is primarily based on regulations of disclosure, as approved by the Iranian Capital Market Supreme Council. These evaluations are based on the management disclosure practices demonstrated in firm annual reports, quarterly reports, management forecasts, and additional information regarding timeliness and reliability. The firms' disclosure scores have been released by the Iranian Security and Exchange Organization (SEO) from 2003. In this research, we use firms' disclosure scores published by SEO as a measure of the corporate disclosure level.

\subsection{Research Model}

Our empirical model for explaining the relationship between the corporate level of disclosure as reported by a monitoring system and firm-specific characteristic variables is as follows:

$$
\begin{aligned}
& \text { DISCLOS }_{i t}=\alpha+\beta_{1} \text { CEOTEN }_{i t}+\beta_{2} \text { SIZE }_{i t}+\beta_{3} \text { ASSETPLC }_{i t}+\beta_{4} \text { LEV }_{i t}+\beta_{5} \text { ISSUE }_{i t}+\beta_{6} \text { AGE }_{i t}+\beta_{7} \text { PROF }_{i t} \\
& +\beta_{8} \text { LIQUID }_{i t}+\beta_{9} \text { PINREV }_{i t}+\beta_{10} \text { AUDIT }_{i t}+\beta_{11} \text { PEAK }_{i t}+\sum_{i=1}^{n} \beta_{12} \text { INDUSTRY }_{i t}+\sum_{i=1}^{n} \beta_{13} Y \text { INAR }_{i t}+\varepsilon_{i t}
\end{aligned}
$$

Where:

DISCLOS $_{i t}$ : the disclosure score reported by the Securities and Exchange Organization (SEO) at the fiscal year end; the construct of disclosure score consists of two criteria, timeliness and reliability of submitted information to the SEO.

CEOTEN $_{i t}: \quad$ the years that the company has retained the CEO;

$S I Z E_{i t}: \quad$ company's natural logarithm of total assets at the fiscal year end;

$\operatorname{ASSETPLC}_{i t}$ : assets-in-place is the proportion of tangible fixed assets to total assets at the fiscal year end;

$L E V_{i t}$ :

$I S S U E_{i t}:$ calculated as the ratio of total debts to total assets at the fiscal year end;

dichotomous variable equals one if the company issued significant new equity of more than 5 percent of the book value of assets at the beginning of the year, 0 otherwise;

$A G E_{i t}:$ calculated from the date of listing the firm on the TSE;

$P R O F_{i t}$ : the measure of a firm's profitability, as calculated by net earnings after interest and tax to sales in 


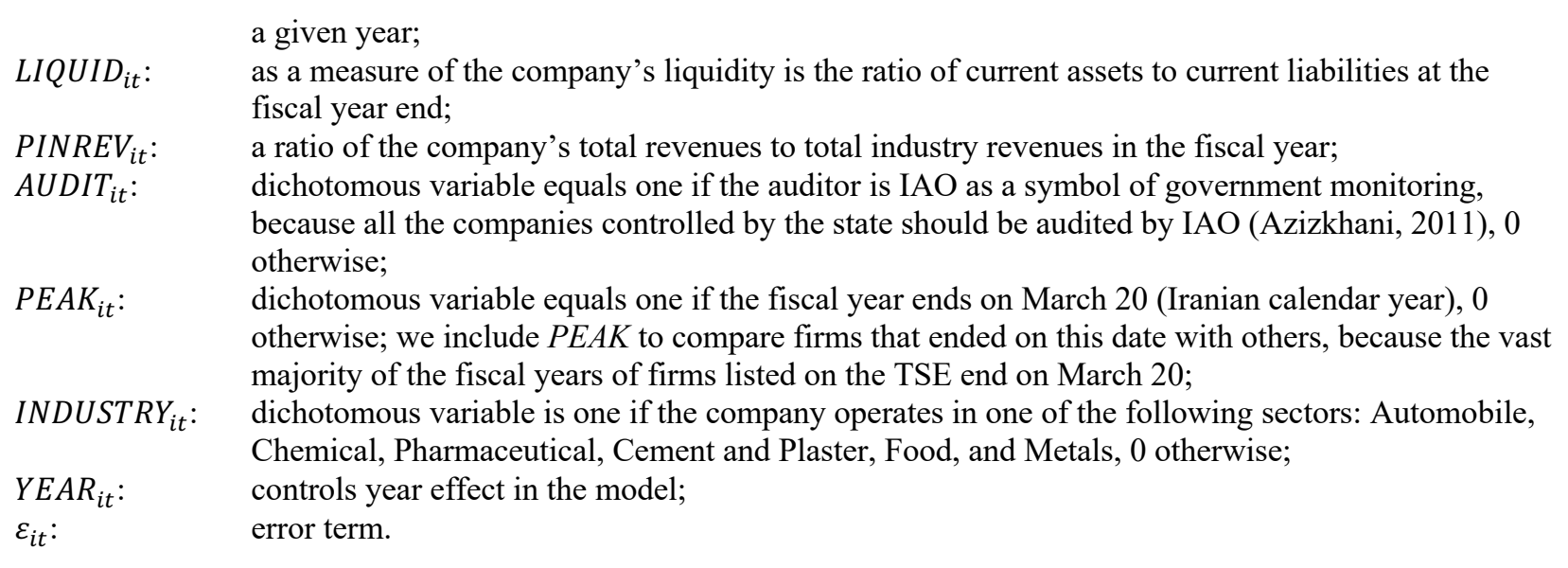

\section{THE EMPIRICAL RESULTS}

\subsection{Descriptive Statistics}

Table 1 reports the descriptive statistics of the variables. To reduce the effect of outliers, we Winsorize variables at the top and bottom 5 percent. The sample consists of 2,719 firm-year observations for 404 firms. We classify the observations into two groups of large firms (46\%) and small firms (54\%) by the median of variable SIZE (13.24). Panel (A) of Table 1 shows that the companies' disclosure scores are smoothly increased from 2003 to 2014 (from 0.379 in 2003 to 0.705 in 2014). Panel (B) presents that DISCLOS has a mean of .55 out of 1 with a standard deviation of 0.254. It also shows that the DISCLOS is unstable across observed companies. DISCLOS varies in a range from 0.078 to 0.934 out of 1 , which suggests a high degree of instability across companies' levels of disclosure.

CEOTEN varies from 1 to 14 years, with a mean and standard deviation of 2.84 and 2.11, respectively. SIZE ranges from 9.78 to 19 with a mean and standard deviation of 13.42 and 1.56 , respectively. These statistics suggest that the deviation is large and indicate a significant skewness. ASSETPLC ranges from $0.2 \%$ to $83 \%$, with a mean of $30 \%$. It reveals that listed firms on the TSE have low ratios of fixed assets/total assets. $L E V$ varies from 0.20 to 1.11 , with a mean of 0.64 . ISSUE shows that only $21 \%$ of listed firms have a large amount of equity issues. $A G E$ has a mean of 13.66 and ranges from 1 to 47 years. The range of profitability $(P R O F)$ is from $-14 \%$ to $97 \%$, with a mean of $21 \%$. LIQUID ranges from $0.2 \%$ to $14.6 \%$, with a mean of $3.7 \%$. AUDIT, with a mean of $23 \%$, indicates that the IAO, as an audit firm with a significant share of the audit market, audits $23 \%$ of the listed companies. PEAK, with a mean of $94 \%$, shows that only 6 percent of the listed firms have a fiscal year other than the calendar year. 
Table 1. Descriptive Statistics

\begin{tabular}{|c|c|c|c|c|c|c|}
\hline \multicolumn{7}{|c|}{ Panel A: Sample Size, Firms' Disclosure Scores } \\
\hline \multirow[t]{2}{*}{ Year } & \multicolumn{2}{|c|}{ FULL SAMPLE } & \multicolumn{2}{|c|}{ LARGE FIRMS } & \multicolumn{2}{|c|}{ SMALL FIRMS } \\
\hline & Obs. & DISCLOS & Obs. & DISCLOS & Obs. & DISCLOS \\
\hline 2003 & 183 & 0.379 & 95 & 0.371 & 88 & 0.387 \\
\hline 2004 & 161 & 0.367 & 81 & 0.347 & 80 & 0.388 \\
\hline 2005 & 193 & 0.373 & 98 & 0.390 & 95 & 0.357 \\
\hline 2006 & 211 & 0.440 & 104 & 0.451 & 107 & 0.430 \\
\hline 2007 & 204 & 0.459 & 98 & 0.441 & 106 & 0.475 \\
\hline 2008 & 210 & 0.451 & 98 & 0.437 & 112 & 0.462 \\
\hline 2009 & 206 & 0.620 & 87 & 0.629 & 119 & 0.613 \\
\hline 2010 & 220 & 0.636 & 93 & 0.639 & 127 & 0.633 \\
\hline 2011 & 315 & 0.649 & 134 & 0.628 & 181 & 0.664 \\
\hline 2012 & 262 & 0.631 & 115 & 0.651 & 147 & 0.616 \\
\hline 2013 & 267 & 0.656 & 118 & 0.666 & 149 & 0.649 \\
\hline 2014 & 287 & 0.705 & 127 & 0.708 & 160 & 0.702 \\
\hline Total & \multicolumn{2}{|c|}{2,719} & \multicolumn{2}{|c|}{$\begin{array}{c}1,248 \\
(46 \%)\end{array}$} & \multicolumn{2}{|c|}{$\begin{array}{c}1,471 \\
(54 \%)\end{array}$} \\
\hline
\end{tabular}

Panel A shows our sample size in each year of the research period and the mean of DISCLOS; where the disclosure score is reported by the Security and Exchange Organization at the end of the fiscal year.

Panel B: Descriptive Statistics for Disclosure (DISCLOS) and Independent Variables. Full Sample =2,719 observations

\begin{tabular}{|l|c|c|c|r|r}
\multicolumn{1}{c}{ Variables } & MEAN & MEDIAN & STD.DEV & MIN & MAX \\
\hline DISCLOS & 0.550 & 0.568 & 0.254 & 0.078 & 0.934 \\
\hline CEOTEN & 2.839 & 2.000 & 2.112 & 1.000 & 14.000 \\
\hline SIZE & 13.417 & 13.241 & 1.563 & 9.778 & 19.009 \\
\hline ASSETPLC & 0.301 & 0.237 & 0.227 & 0.002 & 0.825 \\
\hline LEV & 0.642 & 0.648 & 0.212 & 0.203 & 1.114 \\
\hline ISSUE & 0.214 & 0.000 & 0.410 & 0.000 & 1.000 \\
\hline AGE & 13.656 & 12.000 & 9.469 & 1.000 & 47.000 \\
\hline PROF & 0.208 & 0.164 & 0.218 & -0.139 & 0.971 \\
\hline LIQUID & 0.037 & 0.026 & 0.034 & 0.002 & 0.146 \\
\hline PINREV & 0.094 & 0.024 & 0.162 & 0.000 & 0.632 \\
\hline AUDIT & 0.233 & 0.000 & 0.423 & 0.000 & 1.000 \\
\hline PEAK & 0.937 & 1.000 & 0.243 & 0.000 & 1.000 \\
\hline
\end{tabular}

The descriptive statistics for 2,719 firm-year observations during the period 2003-2014 are reported in the table. DISCLOS is the disclosure score reported by the Security and Exchange Organization at the fiscal year-end. CEOTEN is the year that the company has retained the CEO. SIZE is the company's natural logarithm of total assets at the fiscal year-end. ASSETPLC (assets-in-place) is the proportion of tangible fixed assets/total assets at the fiscal year-end. $L E V$ is calculated as the ratio of total debts to total assets at the fiscal year-end. ISSUE equals one if the company issued significant new equity of more than 5 percent of the book value of assets at the beginning of the year, 0 otherwise. $A G E$ is calculated from the date of listing the firm on the TSE. $P R O F$ is the measure of the firm's profitability that is calculated by net earnings after interest and tax to sales in a given year. LIQUID is calculated as the ratio of current assets to current liabilities at the fiscal year-end. PINREV is a ratio of the company's total revenue to total industry revenue in the fiscal year. AUDIT equals one if the auditor is the IAO, as a representative of government monitoring, 0 otherwise. PEAK equals one if the fiscal year ends on March 20, 0 otherwise.

Panel C: Descriptive Statistics for Disclosure in Each Industry

\begin{tabular}{l|r|r|c}
\hline Industry & n & Percentage & Mean Disclosure Scores \\
\hline Automobile \& Equipment & 303 & $11.14 \%$ & 0.473 \\
\hline Chemical & 236 & $8.68 \%$ & 0.586 \\
\hline Pharmaceutical & 254 & $9.34 \%$ & 0.701 \\
\hline Cement and Plaster & 279 & $10.26 \%$ & 0.686 \\
\hline Food & 221 & $8.13 \%$ & 0.469 \\
\hline Metals & 229 & $8.42 \%$ & 0.535 \\
\hline Others (including 24 industries) & 1,197 & $44.02 \%$ & 0.512 \\
\hline Total & 2,719 & & \\
\hline
\end{tabular}




\subsection{Univariate Analysis}

We separate our sample into two groups of large $(\mathrm{n}=1,248)$ and small $(\mathrm{n}=1,471)$ firms, based on the median of variable SIZE (13.24). We use the t-test and Mann-Whitney u-test to compare the differences between the two groups. Table 2 shows a mean disclosure score (DISCLOS) of 0.54 for large companies and 0.56 for small ones. The comparison indicates a significant difference between the two groups at a 10 percent significance level. The results indicate that small companies disclose more information than large companies do. The results also suggest a significant variation in CEO tenure (CEOTEN) between the two groups of the observations. The univariate analyses of variables SIZE and assets-in-place (ASSETPLC) suggest that the large firms employ more assets in their operations, and a larger portion of their assets is property, plant and equipment. Table 2 presents the mean of $A G E 13.32$ and 13.94 for large and small firms, respectively. Due to the privatization practices in recent years, small firms have a higher mean. The comparison also shows that large companies' profitability is higher than small ones. Small companies have more liquid assets compared to large companies. IAO audits 31 percent of large firms and 17 percent of small firms, which shows a significant difference between them. For other independent variables, we find an insignificant difference between the two groups of firms.

Table 2. Univariate Comparison between Large and Small Firms

\begin{tabular}{l|c|c|c|c|c|c}
\hline & \multicolumn{2}{|c|}{ Large Firms } & \multicolumn{2}{c}{ Small Firms } & \multicolumn{2}{c}{ Mean-Comparison Tests } \\
& Mean & Std. Deviation & Mean & Std. Deviation & t-statistic & $\begin{array}{c}\text { Mann-Whitney u- } \\
\text { test Z-statistic }\end{array}$ \\
\hline DISCLOS & 0.542 & 0.247 & 0.558 & 0.259 & $-1.62^{*}$ & $-1.80^{*}$ \\
\hline CEOTEN & 2.740 & 2.031 & 2.923 & 2.176 & $-2.24^{* *}$ & $-1.98^{* *}$ \\
\hline SIZE & 14.613 & 1.336 & 12.403 & 0.872 & $51.80^{* * *}$ & $39.67^{* * *}$ \\
\hline ASSETPLC & 0.310 & 0.241 & 0.294 & 0.214 & $1.76^{*}$ & 0.05 \\
\hline LEV & 0.644 & 0.203 & 0.640 & 0.219 & 0.44 & 1.44 \\
\hline ISSUE & 0.228 & 0.419 & 0.203 & 0.403 & 1.54 & 1.54 \\
\hline AGE & 13.322 & 10.095 & 13.939 & 8.898 & $-1.69^{*}$ & $-3.56^{* * *}$ \\
\hline PROF & 0.248 & 0.237 & 0.174 & 0.194 & $9.00^{* * *}$ & $8.53^{* * *}$ \\
\hline LIQUID & 0.033 & 0.032 & 0.039 & 0.036 & $-4.45^{* * *}$ & $-4.03^{* * *}$ \\
\hline PINREV & 0.090 & 0.158 & 0.098 & 0.166 & -1.32 & -1.56 \\
\hline AUDIT & 0.314 & 0.464 & 0.165 & 0.371 & $9.34^{* * *}$ & $9.20^{* * *}$ \\
\hline PEAK & 0.937 & 0.244 & 0.937 & 0.243 & 0.00 & 0.01 \\
\hline
\end{tabular}

The symbols ***,**, and * denote statistical significance at $1 \%, 5 \%$, and $10 \%$ levels, respectively.

The descriptive statistics for 2,719 firm-year observations during the period 2003-2014 are reported in the table. The last column shows the test statistics for variations in means between the two groups of large and small firms. DISCLOS is the disclosure score reported by the Security and Exchange Organization at the fiscal year-end. CEOTEN is the year that the company has retained the CEO. SIZE is the company's natural logarithm of total assets at the fiscal year-end. ASSETPLC (assets-in-place) is the proportion of tangible fixed assets to total assets at the fiscal year-end. $L E V$ is calculated as the ratio of total debts to total assets at the fiscal year-end. ISSUE equals one if the company issued significant new equity of more than 5 percent of the book value of assets at the beginning of the year, 0 otherwise. $A G E$ is calculated from the date of listing the firm on the TSE. $P R O F$ is the measure of the firm's profitability that is calculated by net earnings after interest and tax to sales in a given year. LIQUID is calculated as the ratio of current assets to current liabilities at the fiscal year-end. PINREV is a ratio of the company's total revenue to total industry revenue in the fiscal year. $A U D I T$ equals one if the auditor is the IAO, as a representative of government monitoring, 0 otherwise. PEAK equals one if the fiscal year ends on March 20, 0 otherwise.

\subsection{Multivariate Regression Analysis}

In this research, we use regression analysis to examine the relationship between the level of disclosure and firm characteristics of companies listed on the TSE. Before the estimation of the regression model, the degree of multicollinearity among the independent variables and DISCLOS were assessed. Table 3 presents the correlation matrix for the study variables over the period 2003-2014. The Pearson correlations displayed at the lower triangle and the Spearman correlations displayed at the upper triangle. To facilitate discussion, we concentrate on Pearson correlations but note that the Spearman correlations are typically consistent with the Pearson correlations. The first column presents that the correlation coefficients between DISCLOS and independent variables are significant except for CEOTEN, ISSUE, and PINREV. The coefficients for independent variables are less than 0.2 , except for the correlation between $P R O F$ and $L E V(0.45)$. Also, the Spearman coefficients are less than 0.2, except for the correlation between $P R O F$ and $L E V(0.44)$. The small correlations imply that multicollinearity is an insignificant issue. Moreover, 
we use the variance inflation factor (VIF) for multicollinearity assessment. In our regression models, we test the VIF to check for multicollinearity. Myers (1990) argues that if the largest VIF is higher than 10, there is collinearity issue. As an alternative, Bowerman \& O'Connell (1990) suggest that if the average VIF is considerably larger than one, then the regression is likely to yield biased results. In our models, the VIFs are lower than 10, and the average VIFs are close to 1 . Based on those measures, we conclude that the multicollinearity problem within the independent variables is inevident.

Table 3. Correlation Matrix (Spearman top and Pearson bottom)

\begin{tabular}{|c|c|c|c|c|c|c|}
\hline & DISCLOS & CEOTEN & SIZE & ASSETPLC & $L E V$ & ISSUE \\
\hline DISCLOS & & 0.003 & $0.185^{* *}$ & $0.125^{* *}$ & $-0.343^{* *}$ & 0.026 \\
\hline CEOTEN & 0.000 & & $-0.066^{* *}$ & $0.056^{* *}$ & -0.025 & 0.023 \\
\hline SIZE & $0.171^{* *}$ & $-0.052^{* *}$ & & $0.043^{*}$ & -0.037 & 0.017 \\
\hline ASSETPLC & $0.149^{* *}$ & 0.030 & $0.074^{* *}$ & & $-0.128^{* *}$ & $0.067^{* *}$ \\
\hline LEV & $-0.337^{* *}$ & -0.027 & $-0.077^{* *}$ & $-0.090^{* *}$ & & $-0.166^{* *}$ \\
\hline ISSUE & 0.025 & 0.009 & 0.025 & $0.079^{* *}$ & $-0.166^{* *}$ & \\
\hline AGE & $0.053^{* *}$ & $0.038^{*}$ & -0.001 & 0.037 & $0.063^{* *}$ & $-0.050^{* *}$ \\
\hline PROF & $0.277^{* *}$ & -0.033 & $0.229^{* *}$ & -0.007 & $-0.450^{* *}$ & $0.079^{* *}$ \\
\hline LIQUID & $0.068^{* *}$ & -0.004 & $-0.043^{*}$ & $-0.061^{* *}$ & $-0.185^{* *}$ & $0.056^{* *}$ \\
\hline PINREV & -0.018 & 0.006 & -0.023 & 0.008 & 0.002 & -0.025 \\
\hline AUDIT & $-0.140^{* *}$ & $-0.064^{* *}$ & $0.188^{* *}$ & $-0.062^{* *}$ & 0.023 & -0.017 \\
\hline PEAK & $-0.113^{* *}$ & $0.070^{* *}$ & $-0.083^{* *}$ & $-0.093^{* *}$ & 0.035 & 0.000 \\
\hline & $A G E$ & PROF & LIQUID & PINREV & $A U D I T$ & $P E A K$ \\
\hline DISCLOS & $0.074^{* *}$ & $0.335^{* *}$ & $0.073^{* *}$ & -0.022 & $-0.141^{* *}$ & $-0.113^{* *}$ \\
\hline CEOTEN & 0.003 & 0.010 & 0.012 & 0.003 & $-0.046^{*}$ & $0.068^{* *}$ \\
\hline SIZE & 0.036 & $0.197^{* *}$ & $-0.070^{* *}$ & -0.021 & $0.184^{* *}$ & $-0.080^{* *}$ \\
\hline ASSETPLC & -0.030 & 0.020 & -0.007 & 0.007 & $-0.054^{* *}$ & $-0.061^{* *}$ \\
\hline LEV & $0.093^{* *}$ & $-0.438^{* *}$ & $-0.173^{* *}$ & -0.017 & $0.040^{*}$ & $0.050^{* *}$ \\
\hline ISSUE & $-0.068^{* *}$ & $0.081^{* *}$ & $0.048^{*}$ & -0.028 & -0.017 & 0.000 \\
\hline AGE & & $-0.111^{* *}$ & -0.036 & 0.015 & -0.002 & $-0.119^{* *}$ \\
\hline PROF & $-0.052^{* *}$ & & $0.061^{* *}$ & -0.008 & 0.037 & $-0.065^{* *}$ \\
\hline LIQUID & $-0.042^{*}$ & $0.047^{*}$ & & 0.000 & 0.001 & 0.018 \\
\hline PINREV & 0.021 & 0.004 & 0.027 & & -0.020 & 0.004 \\
\hline AUDIT & -0.009 & $0.040^{*}$ & -0.029 & -0.020 & & $0.090^{* *}$ \\
\hline PEAK & $-0.116^{* *}$ & $-0.062^{* *}$ & -0.006 & -0.012 & $0.090^{* *}$ & \\
\hline
\end{tabular}

The symbols $* * * * *$, and $*$ denote statistical significance at $1 \%, 5 \%$, and $10 \%$ levels, respectively.

This table presents a correlation matrix for our variables of interest. The Pearson correlations displayed at the lower triangle and the Spearman's rank correlation coefficients displayed at the upper triangle. DISCLOS is the disclosure score reported by the Security and Exchange Organization at the fiscal year-end. CEOTEN is the year that the company has retained the CEO. SIZE is the company's natural logarithm of total assets at the fiscal year-end. ASSETPLC (assets-in-place) is the proportion of tangible fixed assets to total assets at the fiscal year-end. $L E V$ is calculated as the ratio of total debts to total assets at the fiscal year-end. ISSUE equals one if the company issued significant new equity of more than 5 percent of the book value of assets at the beginning of the year, 0 otherwise. $A G E$ is calculated from the date of listing the firm on the TSE. PROF is the measure of the firm's profitability that is calculated by net earnings after interest and tax to sales in a given year. LIQUID is calculated as the ratio of current assets to current liabilities at the fiscal year-end. PINREV is a ratio of the company's total revenue to total industry revenue in the fiscal year. AUDIT equals one if the auditor is the IAO, as a representative of government monitoring, 0 otherwise. PEAK equals one if the fiscal year ends on March 20, 0 otherwise.

Table 4 presents the results of our analyses for the full sample, large firms, and small firms. The F-ratios are 62.71, 32.12, and 36.39 for the full sample, large firms, and small firms, respectively. Those ratios indicate that the three regression models are statistically significant. The reported adjusted R-squared for the full sample regression model suggests that the firm-specific variables explain 40 percent of the variation in disclosure. The coefficients of determination (adjusted R-squared) for large and small companies are 43 and 42 percent, respectively. The reported adjusted R-squared statistics for all three models are moderate. In the following, we analyze the outcomes of the regression models reported in Table 4. 
Table 4. The Results of Multivariate Regression Models

\begin{tabular}{|c|c|c|c|c|}
\hline & Pred. Sign & Full Sample & Large Firms & Small Firms \\
\hline CONSTANT & + & $\begin{array}{l}0.449^{* * *} \\
(9.85)\end{array}$ & $\begin{array}{l}0.557^{* * *} \\
(6.51)\end{array}$ & $\begin{array}{c}0.023 \\
(0.25)\end{array}$ \\
\hline CEOTEN & + & $\begin{array}{l}0.004^{* *} \\
(2.09)\end{array}$ & $\begin{array}{l}-0.005^{*} \\
(-1.68)\end{array}$ & $\begin{array}{l}0.007^{* * *} \\
(3.01)\end{array}$ \\
\hline SIZE & + & $\begin{array}{l}-0.000 \\
(-0.14)\end{array}$ & $\begin{array}{c}-0.004 \\
(-0.73)\end{array}$ & $\begin{array}{l}0.036^{* * *} \\
(4.88)\end{array}$ \\
\hline ASSETPLC & - & $\begin{array}{l}0.056^{* *} \\
(2.56)\end{array}$ & $\begin{array}{l}0.087^{* * *} \\
(3.13)\end{array}$ & $\begin{array}{c}0.041 \\
(1.18)\end{array}$ \\
\hline LEV & + & $\begin{array}{c}-0.228^{* * *} \\
(-10.79)\end{array}$ & $\begin{array}{l}-0.243^{* * *} \\
(-7.64)\end{array}$ & $\begin{array}{l}-0.209^{* * *} \\
(-7.36)\end{array}$ \\
\hline ISSUE & + & $\begin{array}{c}0.013 \\
(1.36)\end{array}$ & $\begin{array}{r}0.011 \\
(0.79)\end{array}$ & $\begin{array}{r}0.011 \\
(0.83)\end{array}$ \\
\hline AGE & + & $\begin{array}{l}-0.001^{* *} \\
(-2.12)\end{array}$ & $\begin{array}{r}0.001 \\
(1.58)\end{array}$ & $\begin{array}{l}-0.003^{* * *} \\
(-4.43)\end{array}$ \\
\hline PROF & + & $\begin{array}{l}0.130^{* * *} \\
(5.99)\end{array}$ & $\begin{array}{l}0.059^{* *} \\
(2.05)\end{array}$ & $\begin{array}{l}0.231^{* * *} \\
(6.93)\end{array}$ \\
\hline LIQUID & + & $\begin{array}{l}0.267^{* *} \\
(2.32)\end{array}$ & $\begin{array}{c}0.076 \\
(0.43)\end{array}$ & $\begin{array}{l}0.325^{* *} \\
(2.17)\end{array}$ \\
\hline PINREV & + & $\begin{array}{l}-0.055^{* *} \\
(-2.35)\end{array}$ & $\begin{array}{l}-0.031 \\
(-0.91)\end{array}$ & $\begin{array}{l}-0.069^{* *} \\
(-2.18)\end{array}$ \\
\hline AUDIT & $?$ & $\begin{array}{l}-0.054^{* * *} \\
(-5.72)\end{array}$ & $\begin{array}{l}-0.032^{* *} \\
(-2.52)\end{array}$ & $\begin{array}{l}-0.085^{* * *} \\
(-5.85)\end{array}$ \\
\hline PEAK & $?$ & $\begin{array}{c}0.026 \\
(1.48)\end{array}$ & $\begin{array}{l}-0.006 \\
(-0.22)\end{array}$ & $\begin{array}{r}0.020 \\
(0.84)\end{array}$ \\
\hline \multicolumn{5}{|l|}{ INDUSTRY: } \\
\hline $\begin{array}{l}\text { Automobile \& } \\
\text { Equipment }\end{array}$ & $?$ & $\begin{array}{r}0.001 \\
(0.07)\end{array}$ & $\begin{array}{l}-0.025 \\
(-1.34)\end{array}$ & $\begin{array}{r}0.001 \\
(0.08)\end{array}$ \\
\hline Chemical & $?$ & $\begin{array}{l}0.052^{* * *} \\
(3.61)\end{array}$ & $\begin{array}{l}0.036^{*} \\
(1.78)\end{array}$ & $\begin{array}{l}0.069^{* * *} \\
(3.43)\end{array}$ \\
\hline Pharmaceutical & $?$ & $\begin{array}{l}0.167^{* * *} \\
(11.73)\end{array}$ & $\begin{array}{l}0.165^{* * *} \\
(7.33)\end{array}$ & $\begin{array}{l}0.136^{* * *} \\
(7.16)\end{array}$ \\
\hline Cement and Plaster & $?$ & $\begin{array}{l}0.112^{* * *} \\
(7.66)\end{array}$ & $\begin{array}{l}0.104^{* * *} \\
(5.40)\end{array}$ & $\begin{array}{l}0.069^{* * *} \\
(2.74)\end{array}$ \\
\hline Food & $?$ & $\begin{array}{l}-0.031^{* *} \\
(-2.14)\end{array}$ & $\begin{array}{l}-0.051^{* *} \\
(-2.22)\end{array}$ & $\begin{array}{c}-0.019 \\
(-0.97)\end{array}$ \\
\hline Metals & $?$ & $\begin{array}{r}0.007 \\
(0.48)\end{array}$ & $\begin{array}{c}0.026 \\
(1.46)\end{array}$ & $\begin{array}{c}-0.016 \\
(-0.62)\end{array}$ \\
\hline Year fixed & & Included & Included & Included \\
\hline Observations & & 2,719 & 1,248 & 1,471 \\
\hline F (Sig.) & & $\begin{array}{l}62.71 \\
(0.005)\end{array}$ & $\begin{array}{l}32.12 \\
(0.005)\end{array}$ & $\begin{array}{l}36.39 \\
(0.005)\end{array}$ \\
\hline Adjusted $\mathrm{R}^{2}$ & & 0.403 & 0.433 & 0.423 \\
\hline Mean VIF & & 1.65 & 1.72 & 1.78 \\
\hline
\end{tabular}

The symbols ***, **, and * denote statistical significance at $1 \%, 5 \%$, and $10 \%$ levels, respectively. $t$ statistics in parentheses.

This table shows the results of multivariate regression models for the full sample, large firms, and small firms. DISCLOS is the disclosure score reported by the Security and Exchange Organization at the fiscal year-end. CEOTEN is the year that the company has retained the CEO. SIZE is the company's natural logarithm of total assets at the fiscal year-end. ASSETPLC (assets-in-place) is the proportion of tangible fixed assets to total assets at the fiscal year-end. $L E V$ is calculated as the ratio of total debts to total assets at the fiscal year-end. ISSUE equals one if the company issued significant new equity of more than 5 percent of the book value of assets at the beginning of the year, 0 otherwise. $A G E$ is calculated from the date of listing the firm on the TSE. PROF is the measure of the firm's profitability that is calculated by net earnings after interest and tax to sales in a given year. LIQUID is calculated as the ratio of current assets to current liabilities at the fiscal year-end. PINREV is a ratio of the company's total revenue to total industry revenue in the fiscal year. AUDIT equals one if the auditor is the IAO, as a representative of government monitoring, 0 otherwise. PEAK equals one if the fiscal year ends on March 20, 0 otherwise. INDUSTRY equals one if the company operates in one of the following sectors: Automobile, Chemical, Pharmaceutical, Cement and Plaster, Food, and Metals, 0 otherwise. 
CEOTEN. The results from the full sample and small firms regressions support the research hypothesis of a positive relationship between the disclosure level (DISCLOS) and CEO tenure. Our findings are in line with the previous prediction, which indicated that an expanded disclosure policy limits managerial ability to manipulate financial reporting and improves the board of director's ability to assess the CEO. Also, it enhances the level of disclosure as it expected. If we consider the level of disclosure as a performance measurement tool, our evidence is compatible with the research works of Clarkson et al. (1999) and Peterson (2010). However, our result disagrees with Dikolli et al. (2014), who showed that performance measures are more important for performance evaluation purposes early in a CEO's career. However, the result from large firms' regression indicates that there is a negative and significant relationship between DISCLOS and CEO tenure. The finding is consistent with the prediction of Bamber, Jiang, \& Wang (2010).

SIZE. Estimated firm size coefficients for the three regression models present that this variable is significant only in small firms regression. In contrary to our hypothesis, this indicates that small firms tend to disclose more information than large firms. Our results are contradictory to the findings of Firth (1979), Chow \& Wong-Boren (1987), Cooke (1992), Wallace et al. (1994), Raffournier (1995), Zarzeski (1996), Ahmed \& Courtis (1999), Naser et al. (2002), Hossain \& Hammami (2009).

ASSETPLC. The ASSETPLC coefficients in the full sample and large firms regressions are positive and significant at $5 \%$ and $1 \%$ levels, respectively. These findings disagree with our prediction (negative sign), and we reject the hypothesis that firms with a large ratio of ASSETPLC are more likely to have a lower level of disclosure than firms with a small ratio of ASSETPLC. Consistently, Hossain \& Hammami (2009) and De Jong et al. (2011) suggested a positive and significant relation between disclosure and assets-in-place. The coefficient of ASSETPLC in small firms regression is insignificant. This result concurs with the evidence documented by Chow \& Wong-Boren (1987), Hossain et al. (1995), and Raffournier (1995).

$\boldsymbol{L E} \boldsymbol{V}$. In contrast to our prediction, the $L E V$ coefficients in all three regression models are negative and significant that show an inverse relationship between the disclosure and financial leverage. This negative relationship agrees with the results of Eng \& Mak (2003) and Zarzeski (1996). The finding may be justified by the fact that Iranian firms rely mostly on bank loans and thus financing arrangements reduce managers' incentive to provide public disclosure (Baiman \& Verrecchia, 1996; Eng \& Mak, 2003; Frost, 1997; Healy et al. 1999; Healy \& Palepu, 2001). This result is inconsistent with evidence provided by Deloof \& Weets (2003).

ISSUE. As expected, the coefficients in all three regressions are positive but insignificant. The results suggest that there is an insignificant relationship between disclosure and equity issue. Our finding is contradictory to the results documented by Lang \& Lundholm (1993), Clarkson et al. (1999), and (De Jong et al. 2011).

$\boldsymbol{A G E}$. The results of regression models for the full sample and the small firms show that, contrary to our prediction, the coefficients are negative and significant. The findings indicate that younger companies demonstrate a higher disclosure level than older ones. Our findings are inconsistent with the evidence provided by Hossain \& Hammami (2009) and Owusu-Ansah (1998). However, Alsaeed (2006) showed an insignificant relationship between disclosure and firm's age.

PROF. The profitability $(P R O F)$ coefficients are significant and positive. The results indicate that there is a positive and significant relationship between disclosure level and company profitability $(P R O F)$. We conclude that highly profitable companies tend to disclose more information to convey their superior performance. The finding is consistent with the results of Verrecchia (1990), Wallace et al. (1994), Wallace \& Naser (1995), Owusu-Ansah (1998), Naser et al. (2002), Palmer (2008), and Hossain \& Hammami (2009).

LIQUID. The results of the full sample and the small firms regressions show that the LIQUID coefficients are positive and significant. Our regression results suggest that high-liquid companies may disclose more information based on the argument that a company with a healthier financial position has the incentive to disclose more to signal the firm's better position. The findings are consistent with those of Camfferman \& Cooke (2002) for the Netherland. Contrarily, Wallace et al. (1994), Wallace \& Naser (1995), and Naser et al. (2002) reported a negative relationship between disclosure and liquidity. 
PINREV. The coefficients of market share (PINREV), as a surrogate for company relative competitive advantage, are significant and negative in the full sample and the small firms regressions. The result suggests that we should reject our hypothesis that companies with large market share tend to disclose more information than companies with a small market share.

AUDIT. The AUDIT coefficients are negative and significant in all three models. The results are consistent with the finding of Wallace \& Naser (1995). Our results indicate that the companies audited by IAO have lower disclosure scores due to delay in filing their financial reports to the TSE. Such a finding suggests that the appointment of IAO, as an auditor, does not improve the disclosure scores of the firms listed on TSE. The Iranian audit organization (IAO) has a time lag in issuing its audit reports. It is due to the complexity of audit processes in large and government-owned companies that are audited by IAO. Since timeliness is used as one of the factors in calculating the disclosure score, it causes lower disclosure scores for those firms audited by IAO.

INDUSTRY. The coefficients of Chemical, Pharmaceutical, and Cement \& Plaster industries are significant and positive in all three regression models. The evidence indicates that those firms operating in the industries mentioned above disclose more information and have higher disclosure scores. Our result agrees with Cooke (1989a) and Camfferman \& Cooke (2002).

\section{SENSITIVITY ANALYSES}

\subsection{Alternative Measures of CEOTEN}

We run additional regression models using different measures of CEO tenure (CEOTEN) to make sure that multivariate results are robust to different CEOTEN measures. We replace CEOTEN with CEO-SHRT (short period, one year in the position), CEO-MED (medium period, two to four years), and CEO-LONG (long period, more than four years) to examine the sensitivity of the reported results to CEO tenure. Table 5 reports the results of the three regressions models, short tenure (columns 1-3), medium tenure (columns 4-6), and long tenure (columns 7-9), respectively. We document that there is a significant and positive relationship between the disclosure level and long tenure $(C E O-L O N G)$. However, we find a significant and negative relationship between the disclosure and shorttenure. In addition, we report an insignificant relationship between the disclosure and medium- tenure. The results indicate that a company with long CEO tenure tends to have a higher disclosure level than companies with short or medium-tenured CEOs. Our results for additional regression models, regarding the other independent variables, are compatible with the results of previous regression models summarized in Table 4. 
Table 5. The Results of Different Measures of CEO Tenure and the Level of Disclosure

\begin{tabular}{|c|c|c|c|c|c|c|}
\hline & Pred. Sign & $\begin{array}{c}\text { (1) } \\
\text { Full Sample }\end{array}$ & $\begin{array}{c}\text { (2) } \\
\text { Large Firms }\end{array}$ & $\begin{array}{c}\text { (3) } \\
\text { Small Firms }\end{array}$ & $\begin{array}{c}\text { (4) } \\
\text { Full Sample }\end{array}$ & $\begin{array}{c}\text { (5) } \\
\text { Large Firms }\end{array}$ \\
\hline CONSTANT & + & $\begin{array}{l}0.478^{* * *} \\
(10.69)\end{array}$ & $\begin{array}{l}0.564^{* * *} \\
(6.68)\end{array}$ & $\begin{array}{r}0.040 \\
(0.44)\end{array}$ & $\begin{array}{l}0.470^{* * *} \\
(10.40)\end{array}$ & $\begin{array}{l}0.559^{* * *} \\
(6.61)\end{array}$ \\
\hline CEO_SHRT & + & $\begin{array}{l}-0.024^{* * *} \\
(-2.88)\end{array}$ & $\begin{array}{l}-0.004 \\
(-0.32)\end{array}$ & $\begin{array}{l}-0.037^{* * *} \\
(-3.21)\end{array}$ & & \\
\hline CEO_MED & & & & & $\begin{array}{r}0.008 \\
(1.00)\end{array}$ & $\begin{array}{r}0.010 \\
(0.83)\end{array}$ \\
\hline CEO_LONG & + & & & & & \\
\hline SIZE & + & $\begin{array}{c}-0.000 \\
(-0.15)\end{array}$ & $\begin{array}{r}-0.004 \\
(-0.77)\end{array}$ & $\begin{array}{l}0.038^{* * *} \\
(5.08)\end{array}$ & $\begin{array}{l}-0.001 \\
(-0.20)\end{array}$ & $\begin{array}{c}-0.004 \\
(-0.80)\end{array}$ \\
\hline ASSETPLC & - & $\begin{array}{l}0.047^{* *} \\
(2.18)\end{array}$ & $\begin{array}{l}0.079^{* * *} \\
(2.84)\end{array}$ & $\begin{array}{c}0.036 \\
(1.06)\end{array}$ & $\begin{array}{l}0.048 * * \\
(2.25)\end{array}$ & $\begin{array}{l}0.078^{* * *} \\
(2.84)\end{array}$ \\
\hline LEV & + & $\begin{array}{l}-0.230^{* * *} \\
(-10.88)\end{array}$ & $\begin{array}{l}-0.239^{* * *} \\
(-7.51)\end{array}$ & $\begin{array}{l}-0.214^{* * *} \\
(-7.61)\end{array}$ & $\begin{array}{c}-0.232^{* * *} \\
(-10.98)\end{array}$ & $\begin{array}{l}-0.239^{* * *} \\
(-7.53)\end{array}$ \\
\hline ISSUE & + & $\begin{array}{r}0.013 \\
(1.32)\end{array}$ & $\begin{array}{c}0.011 \\
(0.80)\end{array}$ & $\begin{array}{c}0.010 \\
(0.74)\end{array}$ & $\begin{array}{c}0.013 \\
(1.31)\end{array}$ & $\begin{array}{r}0.011 \\
(0.83)\end{array}$ \\
\hline AGE & + & $\begin{array}{l}-0.001^{* *} \\
(-2.29)\end{array}$ & $\begin{array}{r}0.001 \\
(1.38)\end{array}$ & $\begin{array}{l}-0.003^{* * *} \\
(-4.54)\end{array}$ & $\begin{array}{l}-0.001^{* *} \\
(-2.24)\end{array}$ & $\begin{array}{r}0.001 \\
(1.42)\end{array}$ \\
\hline PROF & + & $\begin{array}{l}0.131^{* * *} \\
(6.04)\end{array}$ & $\begin{array}{l}0.062^{* *} \\
(2.18)\end{array}$ & $\begin{array}{l}0.229^{* * *} \\
(6.91)\end{array}$ & & $\begin{array}{l}0.061^{* *} \\
(2.14)\end{array}$ \\
\hline LIQUID & + & $\begin{array}{l}0.261^{* *} \\
(2.27)\end{array}$ & $\begin{array}{c}0.060 \\
(0.34)\end{array}$ & $\begin{array}{l}0.330^{* *} \\
(2.21)\end{array}$ & & $\begin{array}{r}0.060 \\
(0.34)\end{array}$ \\
\hline PINREV & + & $\begin{array}{l}-0.056^{* *} \\
(-2.38)\end{array}$ & $\begin{array}{r}-0.031 \\
(-0.91)\end{array}$ & $\begin{array}{l}-0.066^{* *} \\
(-2.10)\end{array}$ & $\begin{array}{l}-0.056^{* *} \\
(-2.37)\end{array}$ & $\begin{array}{c}-0.032 \\
(-0.93)\end{array}$ \\
\hline AUDIT & $?$ & $\begin{array}{l}-0.056^{* * *} \\
(-5.89)\end{array}$ & $\begin{array}{l}-0.031^{* *} \\
(-2.45)\end{array}$ & $\begin{array}{l}-0.086^{* * *} \\
(-5.94)\end{array}$ & $\begin{array}{l}-0.057^{* * *} \\
(-5.97)\end{array}$ & $\begin{array}{l}-0.031^{* *} \\
(-2.50)\end{array}$ \\
\hline PEAK & $?$ & $\begin{array}{r}0.017 \\
(1.01)\end{array}$ & $\begin{array}{r}-0.020 \\
(-0.80)\end{array}$ & $\begin{array}{r}0.020 \\
(0.85)\end{array}$ & $\begin{array}{r}0.019 \\
(1.12)\end{array}$ & $\begin{array}{c}-0.020 \\
(-0.81)\end{array}$ \\
\hline \multicolumn{7}{|l|}{ INDUSTRY: } \\
\hline $\begin{array}{l}\text { Automobile \& } \\
\text { Equipment }\end{array}$ & $?$ & $\begin{array}{r}0.000 \\
(0.01)\end{array}$ & $\begin{array}{r}-0.027 \\
(-1.41)\end{array}$ & $\begin{array}{r}0.001 \\
(0.03)\end{array}$ & $\begin{array}{r}-0.000 \\
(-0.01)\end{array}$ & $\begin{array}{c}-0.026 \\
(-1.38)\end{array}$ \\
\hline Chemical & $?$ & $\begin{array}{l}0.049^{* * *} \\
(3.43)\end{array}$ & $\begin{array}{c}0.034^{*} \\
(1.70)\end{array}$ & $\begin{array}{l}0.070^{* * *} \\
(3.50)\end{array}$ & $\begin{array}{l}0.049^{* * *} \\
(3.41)\end{array}$ & $\begin{array}{c}0.034^{*} \\
(1.67)\end{array}$ \\
\hline Pharmaceutical & $?$ & $\begin{array}{l}0.164^{* * *} \\
(11.55)\end{array}$ & $\begin{array}{l}0.165^{* * *} \\
(7.36)\end{array}$ & $\begin{array}{l}0.132^{* * *} \\
(6.99)\end{array}$ & $\begin{array}{l}0.162^{* * *} \\
(11.44)\end{array}$ & $\begin{array}{l}0.164^{* * *} \\
(7.36)\end{array}$ \\
\hline $\begin{array}{l}\text { Cement and } \\
\text { Plaster }\end{array}$ & $?$ & $\begin{array}{l}0.109^{* * *} \\
(7.47)\end{array}$ & $\begin{array}{l}0.103^{* * *} \\
(5.35)\end{array}$ & $\begin{array}{l}0.063^{* *} \\
(2.50)\end{array}$ & $\begin{array}{l}0.108^{* * *} \\
(7.38)\end{array}$ & $\begin{array}{l}0.102^{* * *} \\
(5.32)\end{array}$ \\
\hline Food & $?$ & $\begin{array}{l}-0.033^{* *} \\
(-2.23)\end{array}$ & $\begin{array}{l}-0.059^{* *} \\
(-2.57)\end{array}$ & $\begin{array}{l}-0.020 \\
(-1.05)\end{array}$ & $\begin{array}{l}-0.031^{* *} \\
(-2.11)\end{array}$ & $\begin{array}{l}-0.058^{* *} \\
(-2.57)\end{array}$ \\
\hline Metals & $?$ & $\begin{array}{r}0.006 \\
(0.40)\end{array}$ & $\begin{array}{r}0.025 \\
(1.38)\end{array}$ & $\begin{array}{c}-0.019 \\
(-0.75)\end{array}$ & $\begin{array}{l}0.006 \\
(0.39)\end{array}$ & $\begin{array}{r}0.025 \\
(1.39)\end{array}$ \\
\hline Year fixed & & included & included & included & included & included \\
\hline Observations & & 2719 & 1248 & 1471 & 2719 & 1248 \\
\hline F (Sig.) & & $\begin{array}{l}64.86 \\
(0.05)\end{array}$ & $\begin{array}{l}32.88 \\
(0.05)\end{array}$ & $\begin{array}{l}37.79 \\
(0.05)\end{array}$ & $\begin{array}{l}64.43 \\
(0.05)\end{array}$ & $\begin{array}{l}32.92 \\
(0.05)\end{array}$ \\
\hline Adjusted $\mathrm{R}^{2}$ & & 0.403 & 0.430 & 0.423 & 0.401 & 0.431 \\
\hline Mean VIF & & 1.67 & 1.74 & 1.81 & 1.67 & 1.75 \\
\hline
\end{tabular}


(Table 5 continued)

\begin{tabular}{|c|c|c|c|c|c|}
\hline & Pred. Sign & $\begin{array}{c}\text { (6) } \\
\text { SMALL FIRMS }\end{array}$ & $\begin{array}{c}\text { (7) } \\
\text { FULL SAMPLE }\end{array}$ & $\begin{array}{c}\text { (8) } \\
\text { LARGE FIRMS }\end{array}$ & $\begin{array}{c}\text { (9) } \\
\text { SMALL FIRMS }\end{array}$ \\
\hline CONSTANT & + & $\begin{array}{l}0.024 \\
(0.26)\end{array}$ & $\begin{array}{l}0.473^{* * *} \\
(10.56)\end{array}$ & $\begin{array}{l}0.568^{* * *} \\
(6.71)\end{array}$ & $\begin{array}{l}0.045 \\
(0.49)\end{array}$ \\
\hline CEO_SHRT & + & & & & \\
\hline CEO_MED & + & $\begin{array}{c}0.010 \\
(0.86)\end{array}$ & & & \\
\hline CEO_LONG & + & & $\begin{array}{l}0.023^{* *} \\
(2.22)\end{array}$ & $\begin{array}{r}-0.011 \\
(-0.71)\end{array}$ & $\begin{array}{l}0.037^{* * *} \\
(2.69)\end{array}$ \\
\hline SIZE & + & $\begin{array}{l}0.038^{* * *} \\
(5.04)\end{array}$ & $\begin{array}{c}-0.001 \\
(-0.19)\end{array}$ & $\begin{array}{c}-0.004 \\
(-0.79)\end{array}$ & $\begin{array}{l}0.036^{* * *} \\
(4.87)\end{array}$ \\
\hline ASSETPLC & - & $\begin{array}{r}0.039 \\
(1.14)\end{array}$ & $\begin{array}{l}0.048^{* *} \\
(2.22)\end{array}$ & $\begin{array}{l}0.079^{* * *} \\
(2.87)\end{array}$ & $\begin{array}{l}0.036 \\
(1.05)\end{array}$ \\
\hline LEV & + & $\begin{array}{l}-0.219^{* * *} \\
(-7.78)\end{array}$ & $\begin{array}{c}-0.229^{* * *} \\
(-10.81)\end{array}$ & $\begin{array}{l}-0.240^{* * *} \\
(-7.53)\end{array}$ & $\begin{array}{l}-0.212^{* * *} \\
(-7.49)\end{array}$ \\
\hline ISSUE & + & $\begin{array}{c}0.011 \\
(0.76)\end{array}$ & $\begin{array}{c}0.013 \\
(1.30)\end{array}$ & $\begin{array}{c}0.011 \\
(0.81)\end{array}$ & $\begin{array}{c}0.012 \\
(0.86)\end{array}$ \\
\hline AGE & + & $\begin{array}{l}-0.003^{* * *} \\
(-4.45)\end{array}$ & $\begin{array}{l}-0.001^{* *} \\
(-2.39)\end{array}$ & $\begin{array}{c}0.001 \\
(1.42)\end{array}$ & $\begin{array}{l}-0.003^{* * *} \\
(-4.53)\end{array}$ \\
\hline PROF & + & $\begin{array}{l}0.232^{* * *} \\
(6.97)\end{array}$ & $\begin{array}{l}0.134^{* * *} \\
(6.20)\end{array}$ & $\begin{array}{l}0.061^{* *} \\
(2.14)\end{array}$ & $\begin{array}{l}0.236^{* * *} \\
(7.09)\end{array}$ \\
\hline LIQUID & + & $\begin{array}{l}0.324^{* *} \\
(2.16)\end{array}$ & $\begin{array}{l}0.259^{* *} \\
(2.25)\end{array}$ & $\begin{array}{c}0.056 \\
(0.32)\end{array}$ & $\begin{array}{l}0.324^{* *} \\
(2.16)\end{array}$ \\
\hline PINREV & + & $\begin{array}{l}-0.066^{* *} \\
(-2.09)\end{array}$ & $\begin{array}{l}-0.056^{* *} \\
(-2.38)\end{array}$ & $\begin{array}{l}-0.032 \\
(-0.93)\end{array}$ & $\begin{array}{l}-0.069^{* *} \\
(-2.18)\end{array}$ \\
\hline AUDIT & $?$ & $\begin{array}{l}-0.086^{* * *} \\
(-5.97)\end{array}$ & $\begin{array}{l}-0.055^{* * *} \\
(-5.83)\end{array}$ & $\begin{array}{l}-0.032^{* *} \\
(-2.52)\end{array}$ & $\begin{array}{l}-0.086^{* * *} \\
(-5.95)\end{array}$ \\
\hline PEAK & $?$ & $\begin{array}{l}0.026 \\
(1.12)\end{array}$ & $\begin{array}{r}0.017 \\
(1.01)\end{array}$ & $\begin{array}{r}-0.021 \\
(-0.83)\end{array}$ & $\begin{array}{c}0.020 \\
(0.84)\end{array}$ \\
\hline \multicolumn{6}{|l|}{ INDUSTRY: } \\
\hline $\begin{array}{l}\text { Automobile \& } \\
\text { Equipment }\end{array}$ & $?$ & $\begin{array}{r}0.001 \\
(0.06)\end{array}$ & $\begin{array}{l}-0.000 \\
(-0.02)\end{array}$ & $\begin{array}{r}-0.027 \\
(-1.42)\end{array}$ & $\begin{array}{l}0.002 \\
(0.12)\end{array}$ \\
\hline Chemical & $?$ & $\begin{array}{l}0.071^{* * *} \\
(3.55)\end{array}$ & $\begin{array}{l}0.049^{* * *} \\
(3.46)\end{array}$ & $\begin{array}{r}0.033 \\
(1.64)\end{array}$ & $\begin{array}{l}0.069^{* * *} \\
(3.47)\end{array}$ \\
\hline Pharmaceutical & $?$ & $\begin{array}{l}0.131^{* * *} \\
(6.94)\end{array}$ & $\begin{array}{c}0.164^{* * *} \\
(11.56)\end{array}$ & $\begin{array}{l}0.163^{* * *} \\
(7.28)\end{array}$ & $\begin{array}{l}0.135^{* * *} \\
(7.12)\end{array}$ \\
\hline $\begin{array}{l}\text { Cement and } \\
\text { Plaster }\end{array}$ & $?$ & $\begin{array}{l}0.060^{* *} \\
(2.38)\end{array}$ & $\begin{array}{l}0.110^{* * *} \\
(7.53)\end{array}$ & $\begin{array}{l}0.102^{* * *} \\
(5.28)\end{array}$ & $\begin{array}{l}0.067^{* * *} \\
(2.67)\end{array}$ \\
\hline Food & $?$ & $\begin{array}{c}-0.018 \\
(-0.93)\end{array}$ & $\begin{array}{l}-0.032^{* *} \\
(-2.17)\end{array}$ & $\begin{array}{l}-0.057^{* *} \\
(-2.52)\end{array}$ & $\begin{array}{l}-0.018 \\
(-0.95)\end{array}$ \\
\hline Metals & $?$ & $\begin{array}{r}-0.019 \\
(-0.74)\end{array}$ & $\begin{array}{c}0.006 \\
(0.38)\end{array}$ & $\begin{array}{r}0.025 \\
(1.38)\end{array}$ & $\begin{array}{r}-0.017 \\
(-0.66)\end{array}$ \\
\hline Year fixed & & Included & Included & Included & Included \\
\hline Observations & & 1471 & 2719 & 1248 & 1471 \\
\hline F (Sig.) & & $\begin{array}{l}37.20 \\
(0.05)\end{array}$ & $\begin{array}{l}64.66 \\
(0.05)\end{array}$ & $\begin{array}{l}32.90 \\
(0.05)\end{array}$ & $\begin{array}{l}37.60 \\
(0.05)\end{array}$ \\
\hline Adjusted $\mathrm{R}^{2}$ & & 0.419 & 0.402 & 0.430 & 0.422 \\
\hline Mean VIF & & 1.8 & 1.66 & 1.73 & 1.79 \\
\hline
\end{tabular}

The symbols ***,**, and $*$ denote statistical significance at $1 \%, 5 \%$, and $10 \%$ levels, respectively. t statistics in parentheses.

This table shows the results of regressions for the different measures of CEO tenure and the disclosure level. DISCLOS is the disclosure score reported by the Security and Exchange Organization at the fiscal year-end. CEOTEN is the year that the company has retained the CEO. SIZE is the company's natural logarithm of total assets at the fiscal year-end. ASSETPLC (assets-in-place) is the proportion of tangible fixed assets to total assets at the fiscal year-end. $L E V$ is calculated as the ratio of total debts to total assets at the fiscal year-end. ISSUE equals one if the company issued significant new equity of more than 5 percent of the book value of assets at the beginning of the year, 0 otherwise. $A G E$ is calculated from the date of listing the firm on the TSE. PROF is the measure of the firm's profitability that is calculated by net earnings after interest and tax to sales in a given year. LIQUID is calculated as the ratio of current assets to current liabilities at the fiscal year-end. PINREV is a ratio of the company's total revenue to total industry revenue in the fiscal year. AUDIT equals one if the auditor is the IAO, as a representative of government monitoring, 0 otherwise. PEAK equals one if the fiscal year ends on March 20, 0 otherwise. INDUSTRY equals one if the company operates in one of the following sectors: Automobile, Chemical, Pharmaceutical, Cement and Plaster, Food, and Metals, 0 otherwise. 


\subsection{Logistic Regression Analysis}

We employ logistic regression as another sensitivity analysis. In our logistic regression models, the dependent variable is a dichotomous variable that signifies whether a company is characterized as a top-ranked based on its disclosure level. We rank firms based on their disclosure scores in each year. For this purpose, we determine the median of disclosure scores for each industry, and each year. Then each firm with a disclosure score greater than the median of disclosure scores calculated for its related industry and year categorized as a top-ranked firm. More than 50 percent of the observations are assigned to this group.

Table 6 summarizes the results of the logistic regressions. The CEO tenure coefficients of the full sample and small firms regressions are significant and positive. The results are agreeing with those documented in Table 4. In addition, these results are conforming with finding that we report for regression estimated for CEO long tenure in Table 5. However, the CEO tenure coefficient for the small firms regression is statistically insignificant. Our results for logistic regression, regarding the other independent variables, are agreeing with the results of regression models summarized in Tables 4 and 5, except for the ISSUE and Chemical variables. The ISSUE coefficient is positive and significant in full sample regression, albeit that is insignificant in other regressions.

Table 6. The Results of Ranked Firms based on Disclosure Scores in Each Year

\begin{tabular}{|c|c|c|c|c|}
\hline & Pred. Sign & Full Sample & Large Firms & Small Firms \\
\hline CONSTANT & + & $\begin{array}{c}0.612 \\
(1.23)\end{array}$ & $\begin{array}{l}1.881^{*} \\
(1.87)\end{array}$ & $\begin{array}{l}-2.773^{* * *} \\
(-2.72)\end{array}$ \\
\hline CEOTEN & + & $\begin{array}{l}0.053^{* * *} \\
(2.61)\end{array}$ & $\begin{array}{c}0.009 \\
(0.29)\end{array}$ & $\begin{array}{l}0.070^{* *} \\
(2.52)\end{array}$ \\
\hline SIZE & + & $\begin{array}{l}-0.022 \\
(-0.69)\end{array}$ & $\begin{array}{l}-0.071 \\
(-1.10)\end{array}$ & $\begin{array}{l}0.254^{* * *} \\
(3.05)\end{array}$ \\
\hline ASSETPLC & - & $\begin{array}{l}0.542^{* *} \\
(2.26)\end{array}$ & $\begin{array}{l}0.582^{*} \\
(1.82)\end{array}$ & $\begin{array}{l}0.742^{*} \\
(1.93)\end{array}$ \\
\hline LEV & + & $\begin{array}{l}-1.857^{\text {*** }} \\
(-7.76)\end{array}$ & $\begin{array}{l}-2.239^{* * *} \\
(-5.87)\end{array}$ & $\begin{array}{l}-1.623^{* * *} \\
(-5.02)\end{array}$ \\
\hline ISSUE & + & $\begin{array}{l}0.221^{* *} \\
(2.02)\end{array}$ & $\begin{array}{r}0.221 \\
(1.37)\end{array}$ & $\begin{array}{r}0.177 \\
(1.15)\end{array}$ \\
\hline AGE & + & $\begin{array}{l}-0.008^{*} \\
(-1.73)\end{array}$ & $\begin{array}{c}0.008 \\
(1.12)\end{array}$ & $\begin{array}{l}-0.025^{* * *} \\
(-3.44)\end{array}$ \\
\hline PROF & + & $\begin{array}{l}1.696^{* * *} \\
(6.69)\end{array}$ & $\begin{array}{l}0.945^{* * *} \\
(2.80)\end{array}$ & $\begin{array}{l}2.813^{* * *} \\
(6.73)\end{array}$ \\
\hline LIQUID & + & $\begin{array}{l}3.470^{* * *} \\
(2.69)\end{array}$ & $\begin{array}{c}2.500 \\
(1.19)\end{array}$ & $\begin{array}{l}3.834^{* *} \\
(2.26)\end{array}$ \\
\hline PINREV & + & $\begin{array}{l}-0.277 \\
(-1.06)\end{array}$ & $\begin{array}{l}-0.306 \\
(-0.77)\end{array}$ & $\begin{array}{l}-0.228 \\
(-0.64)\end{array}$ \\
\hline AUDIT & $?$ & $\begin{array}{l}-0.416^{* * *} \\
(-3.93)\end{array}$ & $\begin{array}{l}-0.328^{* *} \\
(-2.24)\end{array}$ & $\begin{array}{l}-0.561^{* * *} \\
(-3.42)\end{array}$ \\
\hline PEAK & $?$ & $\begin{array}{r}0.161 \\
(0.85)\end{array}$ & $\begin{array}{l}-0.095 \\
(-0.32)\end{array}$ & $\begin{array}{c}0.194 \\
(0.72)\end{array}$ \\
\hline
\end{tabular}

(Table 6 continued on next page) 


\begin{tabular}{|c|c|c|c|c|}
\hline & Pred. Sign & Full Sample & Large Firms & Small Firms \\
\hline \multicolumn{5}{|l|}{ INDUSTRY: } \\
\hline $\begin{array}{l}\text { Automobile \& } \\
\text { Equipment }\end{array}$ & $?$ & $\begin{array}{r}-0.127 \\
(-0.88)\end{array}$ & $\begin{array}{c}-0.298 \\
(-1.33)\end{array}$ & $\begin{array}{c}-0.099 \\
(-0.50)\end{array}$ \\
\hline Chemical & $?$ & $\begin{array}{r}0.252 \\
(1.63)\end{array}$ & $\begin{array}{r}0.246 \\
(1.09)\end{array}$ & $\begin{array}{c}0.308 \\
(1.40)\end{array}$ \\
\hline Pharmaceutical & $?$ & $\begin{array}{l}1.349^{* * *} \\
(7.75)\end{array}$ & $\begin{array}{l}1.406^{* * *} \\
(5.00)\end{array}$ & $\begin{array}{l}1.114^{* * *} \\
(4.76)\end{array}$ \\
\hline Cement and Plaster & $?$ & $\begin{array}{l}0.834^{* * *} \\
(4.90)\end{array}$ & $\begin{array}{l}0.814^{* * *} \\
(3.59)\end{array}$ & $\begin{array}{c}0.527^{*} \\
(1.69)\end{array}$ \\
\hline Food & $?$ & $\begin{array}{c}-0.220 \\
(-1.38)\end{array}$ & $\begin{array}{c}-0.300 \\
(-1.14)\end{array}$ & $\begin{array}{c}-0.193 \\
(-0.92)\end{array}$ \\
\hline Metals & $?$ & $\begin{array}{r}0.183 \\
(1.14)\end{array}$ & $\begin{array}{l}0.440^{* *} \\
(2.14)\end{array}$ & $\begin{array}{c}-0.234 \\
(-0.84)\end{array}$ \\
\hline Year fixed & & included & included & included \\
\hline Observations & & 2719 & 1248 & 1471 \\
\hline Pseudo $\mathrm{R}^{2}$ & & 0.1344 & 0.1373 & 0.1607 \\
\hline
\end{tabular}

The symbols ***,**, and * denote statistical significance at $1 \%, 5 \%$, and $10 \%$ levels, respectively. $\mathrm{z}$ statistics in parentheses.

This table presents the results of logistic regression models for the full sample, large firms, and small firms. DISCLOS equals one if the firm is categorized as a top-ranked firm based on its disclosure score, 0 otherwise. CEOTEN is the year that the company has retained the CEO. SIZE is the company's natural logarithm of total assets at the fiscal year-end. ASSETPLC (assets-in-place) is the proportion of tangible fixed assets to total assets at the fiscal year-end. $L E V$ is calculated as the ratio of total debts to total assets at the fiscal year-end. ISSUE equals one if the company issued significant new equity of more than 5 percent of the book value of assets at the beginning of the year, 0 otherwise. $A G E$ is calculated from the date of listing the firm on the TSE. PROF is the measure of the firm's profitability that is calculated by net earnings after interest and tax to sales in a given year. LIQUID is calculated as the ratio of current assets to current liabilities at the fiscal year-end. PINREV is a ratio of the company's total revenue to total industry revenue in the fiscal year. AUDIT equals one if the auditor is the IAO, as a representative of government monitoring, 0 otherwise. PEAK equals one if the fiscal year ends on March 20, 0 otherwise. INDUSTRY equals one if the company operates in one of the following sectors: Automobile, Chemical, Pharmaceutical, Cement and Plaster, Food, and Metals, 0 otherwise.

\section{SUMMARY AND CONCLUSION}

In this research, we investigate the effect of firm-specific characteristics, including CEO tenure, company size, assetsin-place, leverage, equity issue, age, profitability, liquidity, market share, auditor type, and industry type on the disclosure level of companies listed on TSE. We use firms' disclosure scores published by the Iranian Securities and Exchange Organization (SEO) that measure the disclosure level of listed companies. The research data consists of 2,719 firm-year observations from 404 companies listed on the TSE from 2003 to 2014. We employ regression models to analyze the relationship between the disclosure level and the firm-specific characteristics.

We contribute to the disclosure literature as follows. First, as hypothesized, we provide evidence that a longer CEO tenure enhances the level of disclosure. The sensitivity analyses confirm our primary results in regards to CEO tenure. Second, we document that those firms audited by IAO obtain lower disclosure scores due to the delay in filing their financial reports to the TSE. Such a finding suggests that the appointment of IAO, as an auditor, does not improve the level of disclosure of the companies listed on TSE. Third, confirming findings of Cooke (1989a) and Camfferman \& Cooke (2002), we show that the companies operating in Chemical, Pharmaceutical, and Cement \& Plaster industries disclose more information and have a higher disclosure score. Lastly, we document that firm profitability, liquidity, and asset-in-place have a positive effect on the disclosure level. Furthermore, we report that leverage, age, and market share affect the level of disclosure negatively.

There are some limitations in the study that can be improved and refined by future research. First, our study employs the firms' disclosure scores released by SEO as a measure of disclosure level. Further studies could use other methods of measuring corporate disclosure (e.g., separating voluntary and mandatory disclosures). Second, our research focuses on non-financial firms in the Iranian capital market. Therefore, our findings may not be generalizable to those non-financial companies in the country. Finally, the Iranian context may be different. Thus our findings may not be generalizable to other countries that have distinct disclosure environments. Replicating this study in other capital markets is a potential extension of this research. A further suggestion is the investigation of time lag in issuing audit 
reports by IAO, as a cause of lowering the disclosure score for firms audited by IAO, to identify whether the lag is due to nature and specific characteristics of audited firms or related to the quality of audit by IAO

\section{AUTHOR BIOGRAPHIES}

Ali Saeedi Ph.D. and CPA (Minnesota and North Dakota) is an Associate Professor of Accounting in the Business Department at the University of Minnesota, Crookston. Dr. Saeedi has taught accounting courses at undergraduate and graduate levels in Iran, Malaysia, and the United States. His research interests include market-based accounting research, financial reporting, corporate governance, accounting information systems, capital market efficiency, and data analytics in accounting. He has published more than 30 papers in the refereed journals. Email: asaeediv@umn.edu (Corresponding author)

Reza Daghani Ph.D. and IRCFA is a Lecturer of Accounting in the Faculty of Management and Accounting at Allameh Tabataba'i University. Also, he is the director of the strategic planning committee in RPMRG. He received his Ph.D. in Accounting from TMU. His research interests include auditing, disclosure, market timing, and corporate governance. He has published several papers in accounting and auditing refereed journals. E-mail: r.daghani@rpmrg.com

Najmeh Hajian Ph.D. is an Assistant Professor at Khatam University. She received her Ph.D. in Accounting from Tarbiat Modares University. Her research interests include corporate governance, disclosure, and credit rating. Some of her papers have recently been published in peer-reviewed journals. Email: n.hajian@khatam.ac.ir

\section{REFERENCES}

Ahmed, K., \& Courtis, J. K. (1999). Associations between corporate characteristics and disclosure levels in annual reports: A meta-analysis. The British Accounting Review, 31(1), 35-61.

Akhtaruddin, M., Hossain, M. A., Hossain, M., \& Yao, L. (2009). Corporate governance and voluntary disclosure in corporate annual reports of Malaysian listed firms. Journal of Applied Management Accounting Research, 7(1), 1-20.

Ali, A., Klasa, S., \& Yeung, E. (2014). Industry concentration and corporate disclosure policy. Journal of Accounting and Economics, 58(2-3), 240-264.

Allahdad, A. (2010). The relationship between transparency and disclosure with the firm size and the market to book value for listed firms in TSE (Unpublished master's thesis). Alameh Tabatabaei University, Tehran, Iran.

Alsaeed, K. (2006). The association between firm-specific characteristics and disclosure: The case of Saudi Arabia. Managerial Auditing Journal, 21(5), 476-496.

Azizkhani, M. (2011). Auditor type and earnings quality in Tehran Stock Exchange. Quarterly Journal of Securities Exchange, 4(16), 229-246.

Baiman, S., \& Verrecchia, R. E. (1996). The relation among capital markets, financial disclosure, production efficiency, and insider trading. Journal of Accounting Research, 34(1), 1-22.

Bamber, L. S., Jiang, J., \& Wang, I. Y. (2010). What's my style? The influence of top managers on voluntary corporate financial disclosure. Accounting Review, 85(4), 1131-1162.

Barako, D. G. (2007). Determinants of voluntary disclosures in Kenyan companies annual reports. African Journal of Business Management, 1(5), 113-128.

Barrett, M. E. (1977). The extent of disclosure in annual reports of large companies in seven countries. The International Journal of Accounting Education and Research, 12(2), 1-25.

Belkaoui, A., \& Kahl, A. L. (1978). Corporate financial disclosure in Canada (Research Monograph, No. 1). Vancouver, British Columbia, Canada: Canadian Certified General Accountants' Association.

Berglöf, E., \& Pajuste, A. (2005). What do firms disclose and why? Enforcing corporate governance and transparency in Central and Eastern Europe. Oxford Review of Economic Policy, 21(2), 178-197.

Beyer, A., Cohen, D. A., Lys, T. Z., \& Walther, B. R. (2010). The financial reporting environment: Review of the recent literature. Journal of Accounting and Economics, 50(2-3), 296-343.

Botosan, C. A. (1997). Disclosure level and the cost of equity capital. The Accounting Review, 72(3), 323-349. Retrieved from http://www.jstor.org/stable/248475

Botosan, C. A. (2000). Evidence that greater disclosure lowers the cost of equity capital. Journal of Applied Corporate Finance, 12(4), 60-69. Retrieved from http://doi.wiley.com/10.1111/j.17456622.2000.tb00019.x\%5Cnpapers2://publication/doi/10.1111/j.1745-6622.2000.tb00019.x

Bowerman, B. L., \& O’Connell, R. T. (1990). Linear statistical models: an applied approach (2nd ed.). Duxbury, Belmont, CA: PWS-Kent Pub. Co. 
Braendle, U. C., Omidvar, A., \& Tehraninasr, A. (2013). On the specifics of corporate governance in Iran and the Middle East. Corporate Ownership and Control, 10(3), 49-62.

Butler, M., Kraft, A., \& Weiss, I. S. (2007). The effect of reporting frequency on the timeliness of earnings: The cases of voluntary and mandatory interim reports. Journal of Accounting and Economics, 43(2-3), 181-217.

Buzby, S. L. (1975). Company size, listed versus unlisted stocks, and the extent of financial disclosure. Journal of Accounting Research, 13(1), 16-37.

Camfferman, K., \& Cooke, T. E. (2002). An analysis of disclosure in the annual reports of U.K and Dutch Companies. Journal of International Accounting Research, 1(1), 3-30.

Chau, G. K., \& Gray, S. J. (2002). Ownership structure and corporate voluntary disclosure in Hong Kong and Singapore. The International Journal of Accounting, 37(2), 247-265.

Choi, F. D. S. (1973). Financial disclosure and entry to the European Capital Market. Journal of Accounting Research, 11(2), $159-175$.

Chow, C. W., \& Wong-Boren, A. (1987). Voluntary financial disclosure by Mexican corporations. Accounting Review, 62(3), 533-541.

Clarkson, P. M., Kao, J. L., \& Richardson, G. D. (1999). Evidence that Management Discussion and Analysis (MD\&A) is a part of a firm's overall disclosure package. Contemporary Accounting Research, 16(1), 111-134.

Cole, J. (2016). Iran is open for business. What does this mean for the global economy? Retrieved from https://www.thenation.com/article/iran-is-open-for-business-what-does-this-mean-for-the-global-economy/

Cooke, T. E. (1989a). Disclosure in the corporate annual reports of Swedish companies. Accounting and Business Research, 19(74), 113-124.

Cooke, T. E. (1989b). Voluntary corporate disclosure by Swedish companies. Journal of International Financial Management \& Accounting, 1(2), 171-195.

Cooke, T. E. (1992). The impact of size, stock market listing and industry type on disclosure in the annual reports of Japanese listed corporations. Accounting and Business Research, 22(87), 229-237.

De Jong, A., Verbeek, M., \& Verwijmeren, P. (2011). Firms' debt-equity decisions when the static tradeoff theory and the pecking order theory disagree. Journal of Banking and Finance, 35(5), 1303-1314.

Dedman, E., \& Lennox, C. (2009). Perceived competition, profitability and the withholding of information about sales and the cost of sales. Journal of Accounting and Economics, 48(2-3), 210-230.

Deloof, M., \& Weets, V. (2003). External financing, information disclosure and the timeliness of annual shareholder meetings and financial statement filings in Belgium. Retrieved from

https://www.uantwerpen.be/images/uantwerpen/container1244/files/TEW - Onderzoek/Working Papers/RPS/2003/RPS-2003-014.pdf

Depoers, F. (2000). A cost benefit study of voluntary disclosure: Some empirical evidence from French listed companies. European Accounting Review, 9(2), 245-263.

Diamond, D. W., \& Verrecchia, R. E. (1991). Disclosure, liquidity, and the cost of capital. The Journal of Finance, 46(4), 13251359. Retrieved from http://www.jstor.org/stable/2328861 Accessed : 08-06-2016 $23: 47$

Dikolli, S. S., Keusch, T., Mayew, W., \& Steffen, T. (2014). Using shareholder letters to measure CEO integrity. Working Paper. Retrieved from http://papers.ssrn.com/sol3/Papers.cfm?abstract_id=2131476

Dye, R. A. (1993). Auditing standards, legal liability, and auditor wealth. Journal of Political Economy, 101(5), 887-914.

Eng, L. L., \& Mak, Y. T. (2003). Corporate governance and voluntary disclosure. Journal of Accounting and Public Policy, $22(4), 325-345$.

Ferguson, A., \& Stokes, D. (2002). Brand name audit pricing, industry specialization, and leadership premiums post-Big 8 and Big 6 mergers. Contemporary Accounting Research, 19(1), 77-110.

Ferreira, A. L., Branco, M. C., \& Moreira, J. A. (2012). Factors influencing intellectual capital disclosure by Portuguese companies. International Journal of Accounting and Financial Reporting, 2(2), 278-298.

Firth, M. (1979). The impact of size, stock market listing, and auditors on voluntary disclosure in corporate annual reports. Accounting and Business Research, 9(36), 273-280.

Frost, C. a. (1997). Disclosure policy choices of UK firms receiving modified audit reports. Journal of Accounting and Economics, 23, 163-187.

Ghazali, N. A. M., \& Weetman, P. (2006). Perpetuating traditional influences: Voluntary disclosure in Malaysia following the economic crisis. Journal of International Accounting, Auditing and Taxation, 15(2), 226-248.

Hajian, N., Anvary Rostamy, A. A., Rahmani, A., \& Azar, A. (2015). Investigating effective factors on disclosure scores of Listed companies in Tehran Stock Exchange. Journal of Financial Accounting Research, 7(1), 71-92.

Hansen, G. S., \& Wernerfelt, B. (1989). Determinants of firm performance: The relative importance of economic and organization factors. Strategic Management Journal, 10(5), 399-411.

Hassan, O., \& Marston, C. L. (2010). Disclosure Measurement in the Empirical Accounting Literature - A Review Article. SSRN Electronic Journal. https://doi.org/10.2139/ssrn.1640598

Healy, P. M., Hutton, A. P., \& Palepu, K. G. (1999). Stock performance and intermediation changes surrounding sustained increases in disclosure. Contemporary Accounting Research, 16(3), 485-520.

Healy, P. M., \& Palepu, K. G. (2001). Information asymmetry, corporate disclosure, and the capital markets: A review of the 
empirical disclosure literature. Journal of Accounting and Economics, 31(1), 405-440.

Hossain, M., Ahmad, K., \& Godfrey, J. M. (2005). Investment opportunity set and voluntary disclosure of prospective information: A simultaneous equations approach. Journal of Business Finance and Accounting, 32(5-6), 871-907.

Hossain, M., \& Hammami, H. (2009). Voluntary disclosure in the annual reports of an emerging country: The case of Qatar. Advances in Accounting, 25(2), 255-265.

Hossain, M., Perera, M. H. B., \& Rahman, A. R. (1995). Voluntary disclosure in the annual reports of New Zealand companies. Journal of International Financial Management and Accounting, 6(1), 69-87. Retrieved from http://inderscience.metapress.com/index/M7378K4610501N42.pdf

Kamalian, A., Niknafs, A. A., Afsharizadeh, O., \& Gholamalipoor, R. (2010). A Data Mining Approach for Determining The Most Affecting Factors on Information Disclosure in Tehran stock exchange. Quarterly Journal of Security Exchange, 3(11), 125-144.

Khaleghi Moghadam, H., \& Khalegh, A. (2008). Corporate transparency in Iran and its affecting factors. Journal of Accounting Research (Publication of Faculty of Management and Accounting, Allameh Tabatabai University in Tehran), 21, 3160.

Korajczyk, R. A., \& Levy, A. (2003). Capital structure choice: Macroeconomic conditions and financial constraints. Journal of Financial Economics, 68(1), 75-109.

Lang, M., \& Lundholm, R. (1993). Cross-sectional determinants of analyst ratings of corporate disclosures. Journal of Accounting Research, 31(2), 246-271.

Lang, M., \& Lundholm, R. J. (1996). Corporate disclosure policy and analyst behavior. Accounting Review, 71(4), 467-492. Retrieved from http://search.ebscohost.com.libproxy.umcrookston.edu/login.aspx?direct=true\&db=buh\&AN=9611271989\&site=ehostlive

Leary, M., \& Roberts, M. (2005). Do firms rebalance their capital structures. Journal of Finance, 60(6), 2575-2619. Retrieved from http://www.jstor.org/stable/3694762

Malone, D., Fries, C., \& Jones, T. (1993). An empirical investigation of the extent of corporate financial disclosure in the oil and gas industry. Journal of Accounting, Auditing \& Finance, 8, 249-273.

Marston, C. L., \& Shrives, P. J. (1991). The use of disclosure indices in accounting research: A review article. The British Accounting Review, 23(3), 195-210.

Marston, C. L., \& Shrives, P. J. (1995). A review of the development and use of explanatory models in financial disclosure studies. In 19th European Accounting Association Annual Congress. Bergen, Norway.

Mashayekhi, B., \& Mashayekh, S. (2008). Development of accounting in Iran. International Journal of Accounting, 43(1), 6686.

Meek, G. K., Roberts, C. B., \& Gray, S. J. (1995). Factors influencing voluntary annual report disclosures by U.S., U.K. and Continental European Multinational Corporations. Journal of International Business Studies, 26(3), 555-572.

Mohammadrezaei, F., Mohd-Saleh, N., \& Banimahd, B. (2012). Political economy of corporate governance: The case of Iran. International Journal of Business Governance and Ethics, 7(4), 301-330.

Myers, R. H. (1990). Classical and modern regression with applications (2nd ed.). Boston, MA: PWS-Kent Pub. Co.

Myers, S. C. (1977). Determinants of corporate borrowing. Journal of Financial Economics, 5(2), 147-175.

Naser, K., Al-Khatib, K., \& Karbhari, Y. (2002). Empirical evidence on the depth of corporate information disclosure in developing countries: The case of Jordan. International Journal of Commerce and Management, $12(3$ \& 4), $122-155$.

O’Neill, J., Wilson, D., Purushothaman, R., \& Stupnytska, A. (2005). How solid are the BRICs? Global Economics Paper No: 134, Goldman Sachs. Retrieved from http://www.goldmansachs.com/our-thinking/archive/archive-pdfs/how-solid.pdf

Owusu-ansah, S. (2000). Timeliness of corporate financial reporting in emerging capital markets: Empirical evidence from the Zimbabwe. Accounting \& Business Research, 30(3), 241-254.

Owusu-Ansah, S. (1998). The impact of corporate attributes on the extent of mandatory disclosure and reporting by listed companies in Zimbabwe. The International Journal of Accounting, 33(5), 605-631.

Palmer, P. D. (2008). Disclosure of the impacts of adopting Australian equivalents of International Financial Reporting Standards. Accounting and Finance, 48(5), 847-870.

Peterson, R. (2010). Disclosure and CEO turnover (Doctoral Dissertation, University of Missouri-Columbia). Retrieved from https://hdl.handle.net/10355/12014

Raffournier, B. (1995). The determinants of voluntary financial disclosure by Swiss listed companies. European Accounting Review, 4(2), 261-280.

Sadeghi Moghadam, M. H., \& Norouzi, M. (2012). A critical research in Iranian stock exchange disclosure system. Law Quarterly, 41(2), 131-149.

Singhvi, S. S., \& Desai, H. B. (1971). An empirical analysis of the quality of corporate financial disclosure. The Accounting Review, 46(1), 129-138.

Stanga, G. (1976). Disclosure in published annual reports. Financial Management, 5(4), 42-52.

Stigler, G. J. (1961). The economics of information. Journal of Political Economy, 69(3), 213-225. Retrieved from http://www.jstor.org.libproxy.umcrookston.edu/stable/1829263

Tasker, S. C. (1998). Bridging the information gap: Quarterly conference calls as a medium for voluntary disclosure. Review of 
Accounting Studies, 3(1-2), 137-167.

Tehran Stock Exchange. (2009). Iran's Capital Market. Tehran. Retrieved from http://new.tse.ir/cms/Portals/0/int/Guide to invest in TSE1_1.pdf

The World Bank. (2017). The World Bank in the Islamic Republic of Iran. Retrieved from http://www.worldbank.org/en/country/iran/overview

Urquiza, F. B., Navarro, M. C. A., \& Trombetta, M. (2010). Disclosure theories and disclosure measures. Revista Espanola de Financiacion y Contabilidad, 39(147), 393-415.

Verrecchia, R. E. (1990). Information quality and discretionary disclosure. Journal of Accounting and Economics, 12(4), 365380.

Wallace, R. S. O., \& Naser, K. (1995). Firm-specific determinants of the comprehensiveness of mandatory disclosure in the corporate annual reports of firms listed on the stock exchange of Hong Kong. Journal of Accounting and Public Policy, 14(4), 311-368.

Wallace, R. S. O., Naser, K., \& Mora, A. (1994). The relationship between the comprehensiveness of corporate annual reports and firm characteristics in Spain. Accounting and Business Research, 25(97), 41-53.

Wang, K., O, S., \& Claiborne, M. C. (2008). Determinants and consequences of voluntary disclosure in an emerging market: Evidence from China. Journal of International Accounting, Auditing and Taxation, 17(1), 14-30.

Welker, M. (1995). Disclosure policy, information asymmetry, and liquidity in equity markets. Contemporary Accounting Research, 11(2), 801-827.

Wijewardena, H., \& Roudaki, J. (1997). Undergraduate accounting curriculum: The unique case of Iran. University of Wollongong, Faculty of Business - Accounting \& Finance. Wollongong. Retrieved from https://ro.uow.edu.au/cgi/viewcontent.cgi?article=1056\&context=accfinwp

Zarzeski, M. T. (1996). Spontaneous Harmonization Effects of Culture and Market Forces on Accounting Disclosure Practices. Accounting Horizon, 10(1), 18-37. 
NOTES 